Review

\title{
Arsenite Depletion by Manganese Oxides: A Case Study on the Limitations of Observed First Order Rate Constants
}

\author{
Lily Schacht 10 and Matthew Ginder-Vogel *1) \\ Department of Civil and Environmental Engineering, University of Wisconsin, Madison, WI 53706, USA; \\ lrschacht@wisc.edu \\ * Correspondence: mgindervogel@wisc.edu; Tel.: +1-608-262-0768
}

Received: 7 May 2018; Accepted: 21 June 2018; Published: 27 June 2018

\begin{abstract}
Arsenic (As) contamination of drinking water is a threat to global health. Manganese(III/IV) $(\mathrm{Mn})$ oxides control As in groundwater by oxidizing more mobile $\mathrm{As}{ }^{\mathrm{III}}$ to less mobile $\mathrm{As}^{\mathrm{V}}$. Both As species sorb to the Mn oxide. The rates and mechanisms of this process are the subject of extensive research; however, as a group, study results are inconclusive and often contradictory. Here, the existing body of literature describing $\mathrm{As}^{\mathrm{III}}$ oxidation by Mn oxides is examined, and several potential reasons for inconsistent kinetic data are discussed. The oxidation of As ${ }^{\text {III }}$ by $\mathrm{Mn}(\mathrm{III} / \mathrm{IV})$ oxides is generally biphasic, with reported first order rate constants ranging seven orders of magnitude. Reanalysis of existing datasets from batch reactions of $\mathrm{As}^{\mathrm{III}}$ with $\delta-\mathrm{MnO}_{2}$ reveal that the first order rate constants reported for As depletion are time-dependent, and are not well described by pure kinetic rate models. This finding emphasizes the importance of mechanistic modeling that accounts for differences in reactivity between $\mathrm{Mn}^{\mathrm{III}}$ and $\mathrm{Mn}^{\mathrm{IV}}$, and the sorption and desorption of $\mathrm{As}^{\mathrm{III}}, \mathrm{As}^{\mathrm{V}}$, and $\mathrm{Mn}^{\mathrm{II}}$. A thorough understanding of the reaction is crucial to predicting As fate in groundwater and removing As via water treatment with Mn oxides, thus ensuring worldwide access to safe drinking water.
\end{abstract}

Keywords: biogeochemistry; kinetics; arsenic; Mn oxides

\section{Introduction}

Drinking water contamination by inorganic contaminants, such as carcinogenic arsenic (As), is a major threat to global health [1]. The ability to predict the fate of contaminants in groundwater is crucial for ensuring continued access to safe drinking water. To achieve this goal, it is necessary to develop a thorough understanding of the interaction of trace minerals phases with common groundwater contaminants. Minerals, such as manganese (Mn) (hydr)oxides, present in the aquifer, have the capacity to sorb and/or react with many common contaminants, thereby altering their environmental fate [2-4]. Manganese is the second-most abundant transition metal in the Earth's crust, making up approximately $0.1 \%$ of the total mass [5]. In oxidizing subsurface environments, dissolved $\mathrm{Mn}$ frequently precipitates as Mn (hydr)oxides. For simplicity, we will refer to all Mn (hydr)oxides as Mn oxides. Over 30 of these minerals have been identified throughout the natural environment, and are found in diverse locations, from salt- and fresh-water bodies to the desert [5]. Mn oxides play a significant role in controlling aqueous contaminant fate, due in part to their ubiquitous appearance as coatings on mineral surfaces and in places with water, like in bedrock fractures [5].

Mn oxides are considered one of the strongest naturally-occurring oxidizing agents, and have large sorption capacities [6-8]. The environmentally relevant oxidation states of $\mathrm{Mn}$ are $+\mathrm{II},+\mathrm{III}$, and $+\mathrm{IV}$. The standard reduction potential for $\mathrm{MnO}_{2(\mathrm{~s})}$ to $\mathrm{Mn}_{(\mathrm{aq})}^{\mathrm{II}}$ is $1.23 \mathrm{~V}$, compared to less than 
$0.7 \mathrm{~V}$ for reduction of colloidal Fe oxides, making $\mathrm{Mn}^{\mathrm{IV}}$ oxide reduction more thermodynamically favorable [9]. Additionally, Mn oxides exhibit high sorption capacities, with specific surface areas (SSAs) up to the order of $100 \mathrm{~m}^{2} / \mathrm{g}[10,11]$. These traits allow Mn oxides to have an impact on the biogeochemical cycling of many environmental contaminants, including organic contaminants [4], selenium (Se) [12-14], chromium (Cr) [15,16], uranium (U) [17,18], and arsenic.

Arsenic (As) groundwater contamination is a major health threat to 140 million people worldwide [1]. Exposure to As, a known carcinogen, causes pulmonary, epidermal, liver, and kidney problems [19-22]. The fate of As in the subsurface is controlled, in part, by Mn oxides and aqueous $\mathrm{Mn}(\mathrm{II})$, due to the redox chemistry of As [23-25]. The mobile As ${ }^{\mathrm{III}}$ oxidation state is more toxic than the relatively immobile $\mathrm{As}^{\mathrm{V}}$ state [26]. The oxidation of $\mathrm{As}^{\mathrm{III}}$ to $\mathrm{As}^{\mathrm{V}}$ by Mn oxides can be described by the general reaction given in Equation (1).

$$
\mathrm{Mn}^{\mathrm{III}, \mathrm{IV}} \text { oxides }+\mathrm{As}^{\mathrm{III}} \rightarrow \mathrm{Mn}^{\mathrm{IIIIII}}+\mathrm{As}^{\mathrm{V}}
$$

Elevated As and Mn concentrations are frequently correlated in groundwater [22,27-32]. Concentrations of As and Mn in these studies were as high as $1340 \mu \mathrm{g} / \mathrm{L}$ [28] and $4000 \mu \mathrm{g} / \mathrm{L}$ [27], respectively. An aggregation of many studies shows that Mn contamination $(>400 \mu \mathrm{g} / \mathrm{L})$ typically occurs in more shallow groundwater than As contamination $(>10 \mu \mathrm{g} / \mathrm{L})$ [25]. Furthermore, As depletion from solution can be predicted by sediment Mn oxide concentration [33]. Observational field studies must be used in conjunction with laboratory experiments to quantitatively and mechanistically understand the interactions of As and $\mathrm{Mn}$ in the subsurface.

Careful experimental design and consistent results are required for the successful application of the results of laboratory data to field systems. Previous experimental research on As ${ }^{\text {III }}$ oxidation and sorption with $\mathrm{Mn}$ oxides describes a wide range of reaction rates and multiple plausible reaction schemes [34-37]. The oxidation of As ${ }^{\mathrm{III}}$ by Mn oxides is characterized by biphasic kinetics, with a fast initial phase followed by a slower phase [37,38]. In this review, we first examine possible causes of inconsistent kinetic data. Then, we describe the current understanding of the reaction mechanism that dictates the second phase of the reaction. For simplicity, the kinetics and reaction mechanism are first explained using data collected at ambient temperature $\left(25^{\circ} \mathrm{F}\right)$ and circumneutral $\mathrm{pH}(6-8)$. The effects of $\mathrm{pH}$, temperature, other metal oxides, competitive ions, and additional environmental factors are considered separately. Finally, we explore the next steps in applying the information gained by decades of research on As(III) removal by Mn oxides. A thorough understanding of As ${ }^{\mathrm{III}}$ oxidation by Mn oxides presents a critical opportunity for reducing the impact of As on human health, by predicting and controlling As in drinking and irrigation water.

\section{Mn Oxide Structure}

In environmental settings, Mn oxides commonly occur in a wide range of structures, average $\mathrm{Mn}$ oxidation numbers (AMONs), and particle sizes, and therefore, have variable reactivities. The basic unit of Mn oxide minerals is the $\mathrm{MnO}_{6}$ octahedra, which primarily forms tunnel and/or layered structures (Figure 1). Tunnel structure $\mathrm{Mn}$ oxides contain a sequence of edge-sharing $\mathrm{MnO}_{6}$ octahedra, with either rectangular or square cross sections. Cations (e.g., sodium $(\mathrm{Na})$ or potassium $(\mathrm{K})$ ) and / or water partially fill the larger tunnels [5]. Layered Mn oxide minerals (phyllomanganates), consist of sheets of edge-sharing $\mathrm{MnO}_{6}$ octahedra with cations and water molecules in the interlayers [5]. The Mn oxide structure formed is a function of many environmental conditions (e.g., temperature, pressure, presence of oxygen, presence of Mn-oxidizing microorganisms) during the mineral's formation [5,39-41]. 


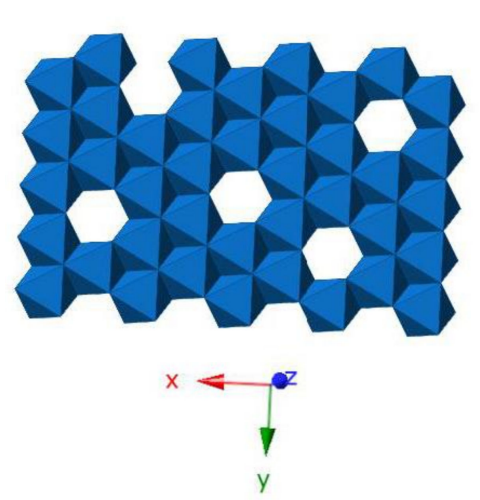

(a)

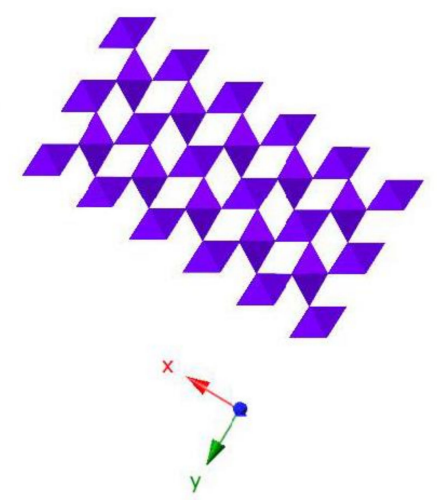

(b)

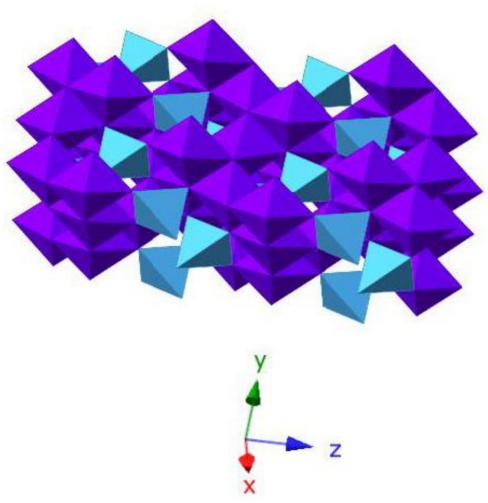

(c)

Figure 1. Mineral structure of various $\mathrm{Mn}$ oxides. (a) Birnessite, a $\mathrm{Mn}^{\mathrm{IV}}$ phyllomanganate; (b) Manganite, a $1 \times 1$ tunnel structure; (c) Hausmannite, a mixed $\mathrm{Mn}^{\mathrm{II}}$, $\mathrm{Mn}^{\mathrm{III}}$ phyllomanganate.

Thermodynamic and kinetic considerations impact the type and subsequent reactivity of $\mathrm{Mn}$ oxides formed in the environment. In anoxic conditions and at low $\mathrm{pH}$, dissolved $\mathrm{Mn}^{\mathrm{II}}$ is stable, while $\mathrm{Mn}^{\mathrm{III}}$ and $\mathrm{Mn}^{\mathrm{IV}}$ are thermodynamically favored under oxic conditions and at high $\mathrm{pH}$ [2]. However, the oxidation of $\mathrm{Mn}^{\mathrm{II}}$ involves a high activation energy, and thus, is a kinetically slow process [42]. In environmental settings, Mn oxide formation is commonly catalyzed by mineral surfaces and microorganisms [39,43,44]. Biogenic Mn oxides are typically phyllomanganates, similar in structure to $\delta-\mathrm{MnO}_{2}$ or acid birnessite $[39,45,46]$. Generally, biogenic Mn oxides are more reactive than synthetic abiotic Mn oxides as a result of their poorly crystalline structure [47].

Defect-site and structural variability play an important role in determining Mn oxide reactivity. For example, under-coordinated oxygen atoms at inner-layer vacancies and particle edges are often sites of oxidation and sorption. The combination of vacancy and edge sites are often referred to as reactive sites; however, As ${ }^{\mathrm{III}}$ oxidation occurs only at edge sites [36]. Still, vacancies result in increased reactivity with respect to $\mathrm{As}^{\mathrm{III}}$, by enhancing sorption of $\mathrm{Mn}^{\mathrm{II}}$ [48]. Layered $\mathrm{Mn}$ oxides have more vacancies and edge sites than tunnel structures, typically resulting in higher As oxidation rate constants and capacities [38,49]. Additionally, $\mathrm{Mn}^{\mathrm{III}}$ edge sites react more slowly than $\mathrm{Mn}^{\mathrm{IV}}$ sites, resulting in decreased As(III) oxidation rates [48]. The reactivity of Mn oxides, with respect to As ${ }^{\mathrm{III}}$ oxidation, may increase with increasing vacancies, decreasing crystallite size, and increasing AMON [48,50,51]. However, in the context of As ${ }^{\mathrm{III}}$ oxidation, the exact relationship between Mn oxide reactivity, and these parameters remains poorly understood [38,50,52].

Thorough physical and chemical characterization of Mn oxides used in experiments is essential to parsing the various factors in controlling $\mathrm{As}{ }^{\mathrm{III}}$ oxidation. Comparison of oxidation rates between studies requires solid phase characterization, including, but not limited to, mineral phase fractions, chemical composition, AMON, crystallite size, and point of zero charge (PZC) [51,53-55]. This is important both at the start of the experiment, and throughout the experiment, because the mineral structure changes throughout the reaction [56,57]. Characterization of environmental Mn oxides presents unique challenges, since they frequently occur as poorly crystalline, fine-grained particles or coatings on other minerals, and are often substituted with Fe [5].

In laboratory settings, $\delta-\mathrm{MnO}_{2}$, a type of birnessite, is often used as an analog for naturally occurring minerals. Methods for synthesizing $\delta-\mathrm{MnO}_{2}$, hausmannite, manganite, partidgeite, cryptomelane, pyrolusite, and todorokite are variations of those described in McKenzie (1971) [10,58,59]. Additionally, these modified methods can be used to obtain Mn oxide minerals at a range of SSAs, fractions of cations in interlayers, and $\mathrm{Mn}^{\mathrm{III}}$ substitutions [51,59-61]. Biogenic Mn oxides may be created, in lab, using Mn oxidizing bacteria (bacteriogenic) or fungi (mycogenic), which results in poorly crystalline minerals that are intimately associated with organic matter, resulting in minerals with a large range of AMON and sorption capacities [39,45,46,62]. 
To further complicate the comparison of rate data across studies, the nomenclature used to describe synthetic minerals is inconsistent. For example, acid birnessite has been used to describe both triclinic and hexagonal birnessite $[4,50]$. The commonly used $\delta-\mathrm{MnO}_{2}$ is also referred to by more general terms, including hydrated Mn oxide (HMO) and birnessite [63,64]. Remucal and Ginder-Vogel (2014) delineate several Mn oxides commonly used in experimental studies [4]. There is significant room for improvement regarding consistency in mineral synthesis and nomenclature across studies.

\section{As ${ }^{\mathrm{III}}$ Depletion Rate Law}

Advances in analytical techniques have greatly increased the availability of reliable kinetic data, resulting in a better understanding of the initial reaction rate [65]. For example, Oscarson et al. (1983) reported a decrease in reaction rate after $30 \mathrm{~min}$, but were unable to collect quantitative data from earlier timepoints [38]. In contrast, Ginder-Vogel et al. (2009) determined rate constants for a similar system with sub-second resolution by using quick X-ray absorption spectroscopy (Q-XAS) [63]. Despite these developments, the current understanding of the factors impacting the rate of As oxidation by Mn oxides remains limited. Observed first order rate constants for aqueous As ${ }^{\text {III }}$ depletion, in the presence of different Mn oxides, span several orders of magnitude $\left(5.3 \times 10^{-1}\right.$ to $4.9 \times 10^{3} \mathrm{~h}^{-1}$ for $\delta-\mathrm{MnO}_{2}, 1.2 \times 10^{-4}$ to $4.9 \times 10^{3} \mathrm{~h}^{-1}$, for all Mn oxides) (Figure 2, Table S1). We aggregated reported rate constants and the corresponding experimental conditions, including $\mathrm{pH}$, temperature, initial $\mathrm{As}^{\mathrm{III}}$ concentration, initial Mn oxide concentration, SSA when reported, and AMON when reported. Statistical analyses show no significant trend $(\alpha=0.05)$ between the rate constants and experimental conditions across studies.

The As ${ }^{\mathrm{III}}$ depletion rate is critical for obtaining order of magnitude estimates of $\mathrm{As}^{\mathrm{III}}$ removal rate from solution. Since $\mathrm{As}^{\mathrm{V}}$ is less mobile and toxic than $\mathrm{As}{ }^{\mathrm{III}}$, an $\mathrm{As}{ }^{\mathrm{III}}$ depletion rate law is essential for predicting As mobility in subsurface systems. In order to evaluate the validity of the observed first order approximation commonly used, we must first consider the entire reaction mechanism.

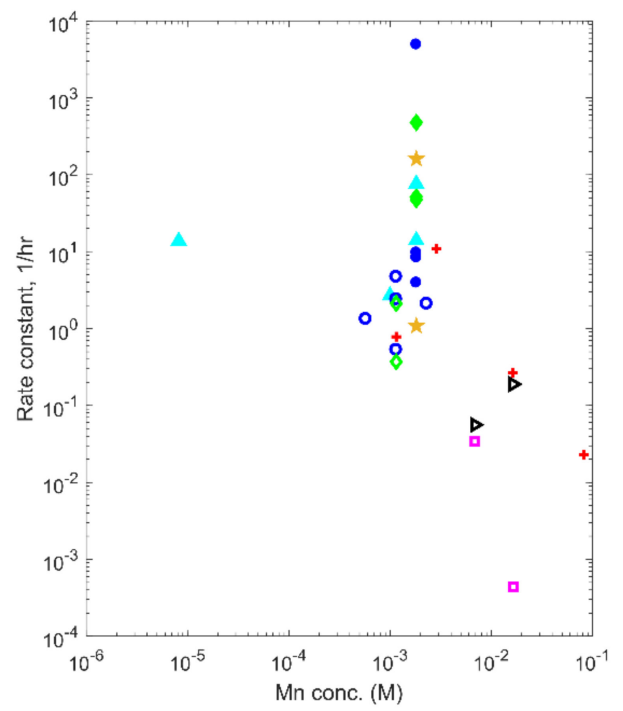

(a)

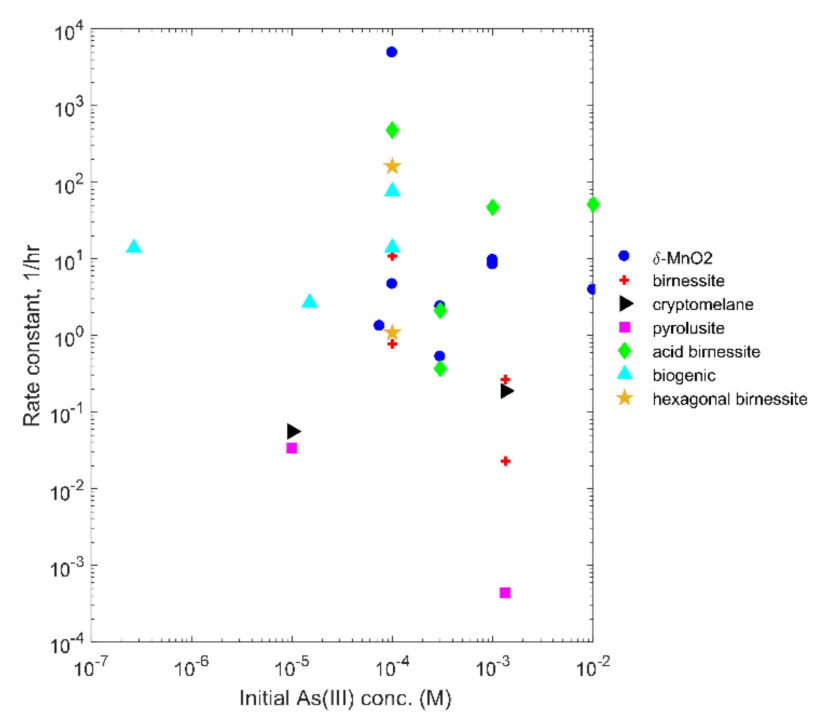

(b)

Figure 2. Observed rate constants for first order depletion of $A s^{\mathrm{III}}$ for experiments at $\mathrm{pH}$ values between 6 and 8 at $25^{\circ} \mathrm{C}$. (a) Reported rate constants vs initial Mn oxide concentration. Closed symbols represent points where the Mn oxide concentration in molarity was reported. Open symbols represent points where we calculated the Mn oxide concentration by assuming pure $\mathrm{MnO}_{2}$. (b) Reported rate constants vs initial As ${ }^{\mathrm{III}}$ concentration [34,38,50,55,66-73]. 
The depletion of As ${ }^{\mathrm{III}}$ from solution is a multistep mechanism, and includes sorption, electron transfer, and desorption (Figure 3) [74]. The overall rate of As ${ }^{\mathrm{III}}$ removal from solution is dependent on several factors, including the As concentration, density, and types of reactive sites on the Mn oxide (>Mn), and proton activity $[4,50,74]$. Thus, an equation describing the depletion rate of $A s^{\mathrm{III}}$ in the presence of Mn oxides should take the form of Equation (1), where $\alpha, \beta, \gamma$, and $\varepsilon$ represent the reaction order with respect to a given component.

$$
\begin{gathered}
\mathrm{r}_{\mathrm{As}} \mathrm{III}=\frac{\mathrm{d}\left[\mathrm{As}^{\mathrm{III}}\right]}{\mathrm{dt}}=-k\left[\mathrm{As}^{\mathrm{III}}\right]^{\alpha}\left[>\mathrm{Mn}^{\mathrm{IV}}\right]^{\beta}\left[>\mathrm{Mn}^{\mathrm{III}}\right]^{\gamma}\left\{\mathrm{H}^{+}\right\}^{\epsilon} \\
\mathrm{r}_{\mathrm{As}}{ }^{\mathrm{III}}=-k_{o b s}\left[\mathrm{As}^{\mathrm{III}}\right]^{\alpha}
\end{gathered}
$$

In general, when an observed first order rate constant, with respect to As ${ }^{\mathrm{III}}$ depletion, is reported, it incorporates the effect of the other possible reactants into the rate constant (Equation (3), $\alpha=1$ ). In a well buffered solution at high [Mn]/[As] this is an acceptable approach to determining pseudo first order rate constants [75,76]. This method assumes that the proton activity and Mn surface site concentrations remain constant over the time period being analyzed and can thus be incorporated into an observed, first order rate constant. This approach yields two fitting parameters for the experimental data: rate constant $\left(k_{o b s}\right)$ and the reaction order $(\alpha)$ with respect to As ${ }^{\mathrm{III}}$ concentration (Equation (3)). Existing work generally fits the kinetic data with integer reaction orders leading to a first $[38,50]$ or second order reaction $[77,78]$. However, the multistep nature of the reaction mechanism indicates that the overall rate law is likely much more complicated than an integer reaction order. The oxidation of As ${ }^{\mathrm{III}}$ on Mn oxides can be considered a surface catalyzed reaction, which are typically modeled with non-integer overall reaction orders. For example, the general Langmuir-Hinshelwood model for the reaction of two molecules on a catalyst has non-integer reaction orders for both reactants, and is second order for reactive site concentration [79].

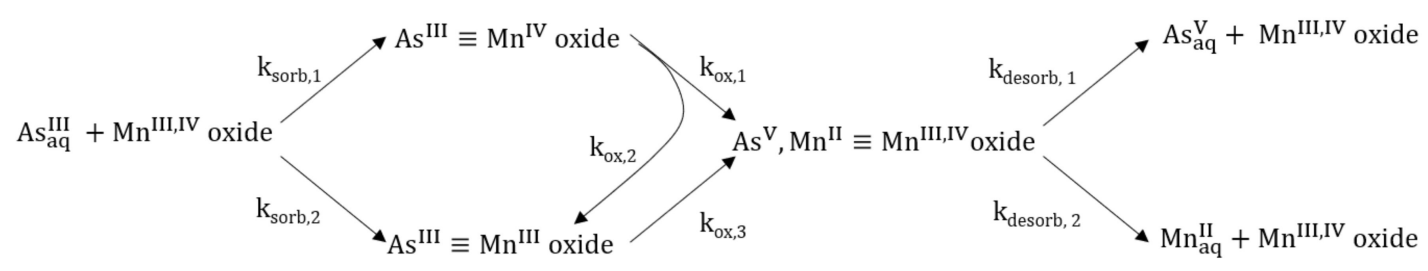

Figure 3. Proposed overall mechanism for As ${ }^{\mathrm{III}}$ depletion by $\mathrm{Mn}^{\mathrm{IIIIV}}$ oxides. Reaction stoichiometries are not shown, because the ratios between different electron transfer pathways (e.g., the relative magnitudes of $\mathrm{k}_{\mathrm{ox}, 1}, \mathrm{k}_{\mathrm{ox}, 2}$, and $\mathrm{k}_{\mathrm{ox}, 3}$ ) are unknown. Mn comproportionation and disproportionation are also not shown, but are important to understanding the overall electron balance [56].

Consideration of the changes in surface site concentration throughout the reaction is necessary for the derivation of a mechanistic model. The relative concentrations of $\mathrm{Mn}^{\mathrm{IV}}$ and $\mathrm{Mn}^{\mathrm{III}}$ surface sites are expected to change throughout the reaction, as $\mathrm{Mn}^{\mathrm{III}}$ is produced as a reaction intermediate [35]. Reaction order with respect to reactive site concentration is more difficult to determine than that of $\mathrm{As}^{\mathrm{III}}$ concentration. An easy approximation is to use the concentration of Mn oxides as a proxy for reactive site concentration. Studies on organic compounds and Mn oxides resulted in reaction orders with respect to $\left[\mathrm{MnO}_{2}\right]$ ranging from 0.04 to 1.37 [4]. The reliability of this proxy is dependent on the mineral composition and structure. For crystalline phyllomanganates, we expect the reactive site concentration to be roughly proportional to mineral concentration, due to the simple stoichiometry between As and Mn. As mineral structure becomes less crystalline, the correlation should weaken because defects increase.

Reactive site concentration is typically approximated by number of sites per unit area (12 sites $/ \mathrm{nm}^{2}$ for $\delta-\mathrm{MnO}_{2}$ and acid birnessite) [55]. This can be converted to a mass basis by 
multiplying by the specific surface area (SSA) of the mineral. However, SSA determined by Brunauer-Emmett-Teller (BET) theory is correlated with suspension $\mathrm{pH}$ and $\mathrm{Na} / \mathrm{Mn}$ content during synthesis, and is not related to crystallite size, as previously believed [51]. Further work is needed to understand the relationship between mineral crystallinity, surface area, and reactivity specifically within the context of As ${ }^{\mathrm{III}}$ oxidation.

It is also important to consider how the mineral composition affects reactivity. Synthesis methods yield minerals with a variety of $\mathrm{Mn}^{\mathrm{III}}$ concentrations and cation $\left(\mathrm{K}^{+}, \mathrm{Na}^{+}\right)$substitutions [10,38,51,80-82]. The reactivity of a Mn surface site is dependent on its oxidation state because $\mathrm{Mn}^{\mathrm{III}}$ may be less reactive than $\mathrm{Mn}^{\mathrm{IV}}$ [48]. As a result, the $\mathrm{Mn}$ reactive site concentrations are split into $\mathrm{Mn}^{\mathrm{III}}$ and $\mathrm{Mn}^{\mathrm{IV}}$ in Equation (2). Additionally, the interlayer cations impact the aggregate structure of the Mn oxide, presumably altering its reactivity [51]. Without accounting for this variability, kinetic data are not comparable across studies, or even across solids from different syntheses, due to the sensitivity of the synthesis method.

The reaction rate is expected to depend on proton activity, due to the $\mathrm{pH}$ dependency of the redox half reactions. While kinetic experiments show a change in observed first order rate constant at different $\mathrm{pHs}[50,73]$, one study determined the reaction order with respect to proton activity to be zero [77]. In experiments examining organic compounds reaction with Mn oxides, the $\left\{\mathrm{H}^{+}\right\}$ reaction order increases with increasing $\mathrm{pH}$ [4]. This implies that the reaction mechanism changes with changing $\mathrm{pH}$. While it cannot be assumed that this correlation translates to the reaction of $\mathrm{As}^{\mathrm{III}}$ on Mn oxides, this finding does indicate that $\mathrm{pH}$ may be an important consideration. In $\mathrm{As}^{\mathrm{III}}$ and $\mathrm{Mn}$ oxide equilibrium experiments, the $\mathrm{pH}$ increased during the reaction when the solution was initially acidic; however, when the solution was initially basic, the $\mathrm{pH}$ decreased from the start of the reaction to the end [49]. This suggests a $\mathrm{pH}$-dependent reaction mechanism is present. This change could be described quantitatively by a full rate law describing As ${ }^{\mathrm{III}}$ depletion by Mn oxides for each mechanism. To move beyond first order approximations and better understand the kinetics of this reaction, the reaction orders, with respect to As concentration, $\mathrm{Mn}^{\mathrm{III}}$ and $\mathrm{Mn}^{\mathrm{IV}}$ site concentration, and proton activity, are required.

\section{Data Analysis}

Despite the ubiquitous usage of observed first order rate constants in mineral surface reactions, there is no standard method to calculate these constants. As a result, values can vary considerably within a single dataset and across studies, making comparison difficult. To demonstrate this, we have re-analyzed data from two experiments performed in Ginder-Vogel et al. (2009) that examined As ${ }^{\text {III }}$ oxidation by $\delta-\mathrm{MnO}_{2}$ [63]. In one experiment, $80 \mathrm{~mL}$ of reaction buffer (5 mM MOPS, $10 \mathrm{mM} \mathrm{NaCl}$ at $\mathrm{pH} 7$ ), with $10 \mathrm{~mL}$ of $10 \mathrm{~g} / \mathrm{L} \delta-\mathrm{MnO}_{2}$ and $10 \mathrm{~mL}$ of $50 \mathrm{mM} \mathrm{As}{ }^{\mathrm{III}}$ in reaction buffer, were mixed in a batch reactor. Samples were taken every $15 \mathrm{~s}$ for $5 \mathrm{~min}$, and analyzed by liquid chromatography inductively coupled plasma mass spectrometry (LC-ICP-MS). A second experiment using Q-XAS was performed using the same relative concentrations as the batch experiments. The resulting data has one-second resolution for $294 \mathrm{~s}$. The experiment analyzed by LC-ICP-MS measures the aqueous As $\mathrm{s}^{\mathrm{III}}$, while the experiment analyzed by Q-XAS measures the fraction of total (aqueous plus sorbed) As present as As ${ }^{I I I}$, which is then multiplied by the total initial As concentration from ICP-MS to yield the total As ${ }^{I I I}$ concentration. Both experiments were performed in triplicate, and the resulting As ${ }^{I I I}$ concentrations are shown in Figure 4a [63]. 
LC-ICP-

(a)

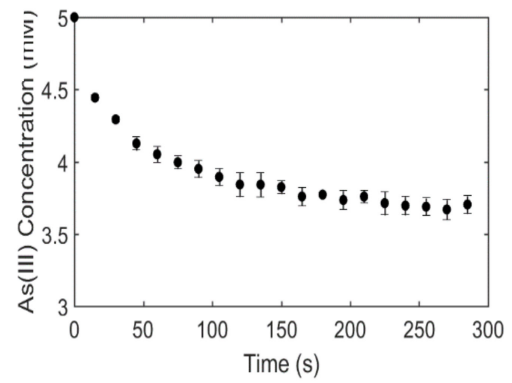

(b)

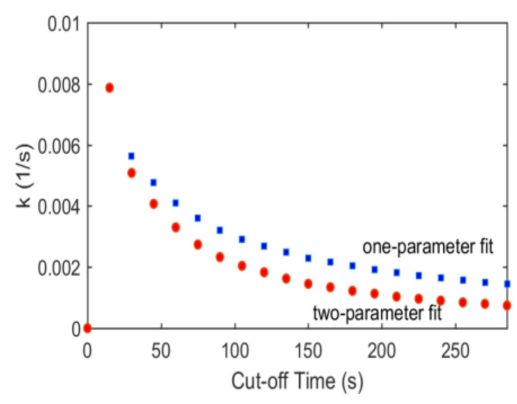

(c)

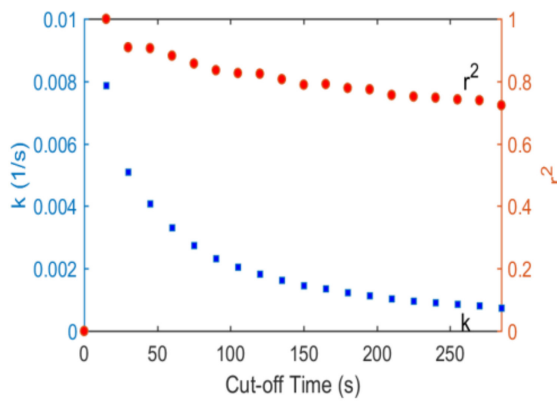

(d)

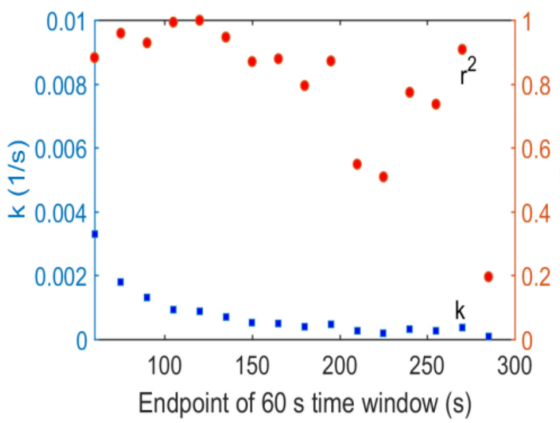

Q-XAS
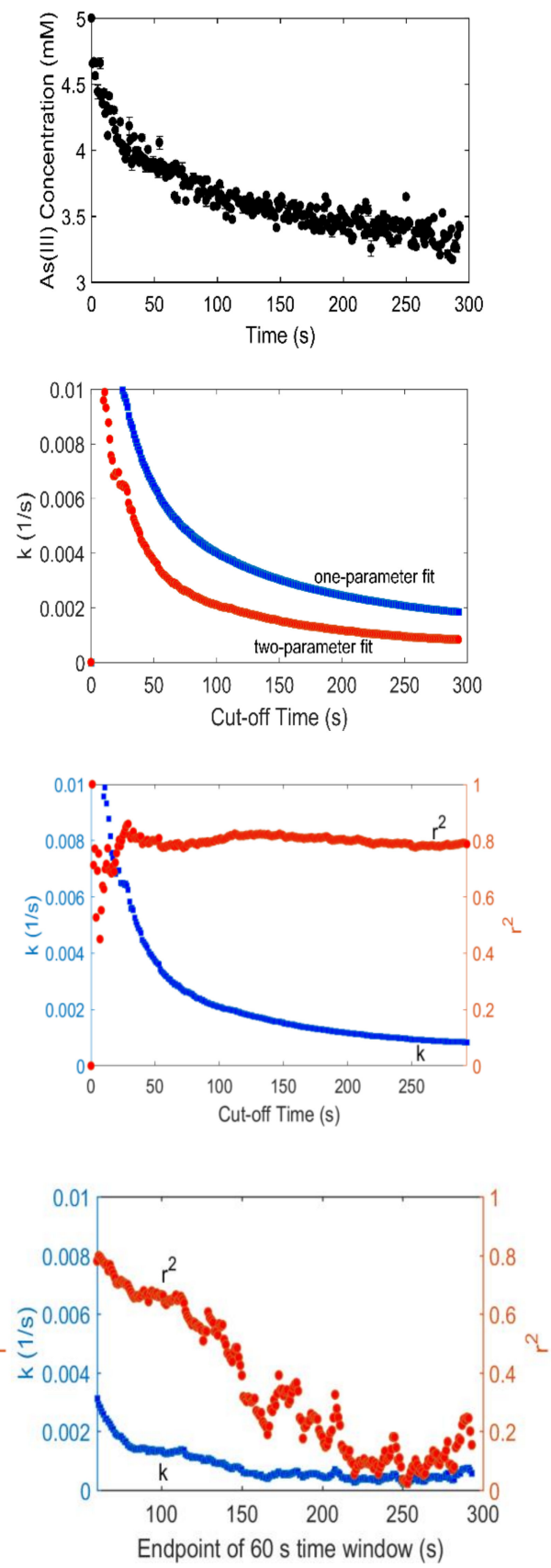

Figure 4. Re-analyzed data from Ginder-Vogel et al. (2009). (a) As ${ }^{I I I}$ concentration vs time; (b) Rate constants calculated using one-parameter (blue squares) and two-parameter (red circles) model; (c) Rate constants calculated from start of reaction to cut-off time compared with $r^{2}$ for that rate constant; (d) Rate constants calculated from $60 \mathrm{~s}$ prior to cut-off time to cut-off time compared with $r^{2}$ for that rate constant.

First order rate constants are typically fit by using a linearized first order rate law (Equation (4)). The line of best fit can be forced through the origin so that there is only one fitting parameter, $k$. However, some choose not to force the line of best fit through the origin in pursuit of a better model fit. This effectively creates an error term, or a two-parameter fit (Equation (5)).

$$
\ln \left(\frac{\mathrm{C}}{\mathrm{C}_{0}}\right)=-k \mathrm{t}
$$




$$
\ln \left(\frac{\mathrm{C}}{\mathrm{C}_{0}}\right)=-k \mathrm{t}+\text { error }
$$

Figure $4 \mathrm{~b}$ displays the rate constants calculated using both the one-parameter and two-parameter fit. These rate constants were calculated by using the data from the initial timepoint to the given cut-off time. The rate constant from the first $60 \mathrm{~s}$ of the Q-XAS dataset is $3.90 \times 10^{-3} \mathrm{~s}^{-1}$ with the one-parameter fit, and $3.12 \times 10^{-3} \mathrm{~s}^{-1}$ with the two-parameter fit (Table 1). The corresponding $r^{2}$ (not shown) indicate that the two-parameter model has a better fit. In fact, the $r^{2}$ is negative beyond $255 \mathrm{~s}$ for the LC-ICP-MS dataset and $80 \mathrm{~s}$ for the Q-XAS dataset. This represents a model fit that is worse than predicting that the $\mathrm{As}{ }^{\mathrm{III}}$ concentration at any timepoint is equal to the average $\mathrm{As}{ }^{\mathrm{III}}$ concentration throughout the reaction.

Table 1. Subset of calculated first order rate constants.

\begin{tabular}{|c|c|c|c|c|}
\hline & \multicolumn{4}{|c|}{$k \times 10^{3}\left(\mathrm{~s}^{-1}\right),\left(r^{2}\right)$} \\
\hline & \multicolumn{2}{|c|}{ LC-ICP-MS } & \multicolumn{2}{|c|}{ Q-XAS } \\
\hline & $60 \mathrm{~s}$ Fit & Best Fit & 60 s Fit & Best Fit \\
\hline \multicolumn{5}{|l|}{ From start to cutff time } \\
\hline One-parameter & $4.09(0.81)$ & $5.64(0.89)^{\mathrm{a}}$ & $3.90(0.69)$ & $34.4(0.68)^{\mathrm{c}}$ \\
\hline Two-parameter & $3.30(0.88)$ & $5.08(0.91)^{\mathrm{a}}$ & $3.12(0.78)$ & $6.25(0.86)^{d}$ \\
\hline \multicolumn{5}{|l|}{$60 \mathrm{~s}$ window } \\
\hline Two-parameter & - & $0.87(0.99)^{b}$ & - & $6.25(0.86)^{d}$ \\
\hline
\end{tabular}

The better fit of the two-parameter model indicates that As ${ }^{\mathrm{III}}$ depletion over the entire reaction period is not adequately described by a first order model. This poor fit is a result of the combination of multiple sorption and electron transfer rates that factor into As ${ }^{\mathrm{III}}$ disappearance from solution, as well as a Mn oxide surface that changes throughout reductive dissolution. The two-parameter model may be used to describe how the reaction progresses with time, but this model would not yield information about the reaction mechanism. The error term has no physical meaning, and thus only indicates if the reaction is well described by a kinetic rate, shown by an error of 0 . Since the two models give us different information about the reaction, it is important to report which fitting method is used, so that the rate constants can be compared across studies. The rate constants determined in the analyses described below use the two-parameter fit.

When reporting rate constants for As ${ }^{\text {III }}$ depletion by Mn oxides, the time range that the rate constants were calculated from is frequently reported [50,63]. To investigate the effect of the timepoint where the data is cut off, observed first order rate constants were determined by using the data presented in Ginder-Vogel et al. (2009) from the start of the reaction to a given cut-off time. For example, the rate constant determined using a cut-off time of $60 \mathrm{~s}$ is calculated using all the data points from 0 to $60 \mathrm{~s}$. The resulting rate constants and fit, as measured by $r^{2}$, are shown in Figure $4 \mathrm{c}$. The rate constant is shown as a function of cut-off time. Both data sets indicate that the rate constant has multiple orders of magnitude variability $\left(10^{-2}-10^{-4} \mathrm{~s}^{-1}\right)$ on relatively small timescales, demonstrating the importance of reporting the time range used. This order of magnitude variability in rate constant was also observed with sequential additions of bisphenol A to Mn oxide [57]. Reductive dissolution of Mn oxides by As ${ }^{\text {III }}$ is characterized by structural changes, rather than simply reducing $\mathrm{Mn}^{\mathrm{IV}}$ to aqueous $\mathrm{Mn}^{\mathrm{II}}$ [56]. As the mineral structure changes, the oxidation affinity of the $\mathrm{Mn}$ atoms changes. Primarily, $\mathrm{Mn}^{\mathrm{III}}$ builds up in $\delta-\mathrm{MnO}_{2}$ during $\mathrm{As}^{\mathrm{III}}$ oxidation, causing increased Jahn-Teller distortion in the mineral [56]. The $\mathrm{Mn}^{\mathrm{III}}$ centers are less reactive than $\mathrm{Mn}^{\mathrm{IV}}$ centers [48]. This results in a decreasing rate constant throughout the experiment, as indicated in Figure 4c.

Despite a poor model fit, the observed first order rate constant is helpful in comparing rates within an experiment when used carefully. The value of achieving the best fit rate law must be weighed with the loss in comparability when comparing two rate constants fit with different time intervals. 
In other words, consider if the quality of information gained by having a perfectly fit rate law justifies comparing a rate constant fit from 0 to $15 \mathrm{~min}$, to one fit from 5 to $30 \mathrm{~min}$. If the goal of the work is to compare rate constant across a single study, it makes sense to aim for consistent time intervals. On the other hand, if the rate constant is going to be used as a model input parameter, the best fit may be more important.

To this end, first order rate constants for the two datasets were calculated using a rolling $60 \mathrm{~s} \mathrm{time}$ window (Figure 4d). For example, the rate constant for the $200 \mathrm{~s}$ cut-off time was calculated using the data from $140 \mathrm{~s}$ to $200 \mathrm{~s}$. The Q-XAS data fits the first order model better at the beginning of the reaction, but as the reaction slows and the As ${ }^{\mathrm{III}}$ concentration levels off, the fit becomes worse. The rate constants associated with the best fits are given in Table 1. The best fit was within the first $60 \mathrm{~s}$ of reaction for all the rate constants except the LC-ICP-MS experiment calculated with the $60 \mathrm{~s}$ window.

Alternate measures of reaction progression may be better suited to comparing different trials. For example, the slope of the plot of $\left[\mathrm{As}^{\mathrm{III}}\right]$ vs time for the first $30 \mathrm{~s}\left(\mathrm{~m}_{30 \mathrm{~s}}\right)$ has the benefit of fitting the reaction for a standard amount of time. If the system is well suited for this measure, the first $30 \mathrm{~s}$ would encompass just the first phase of the reaction. However, $\mathrm{m}_{30 \mathrm{~s}}$ is based on a linear fit of the data. The reliability of this metric is also dependent on having accurate, frequent data collection, so that the value is resistant to outliers, and is not skewed by mixing time at the start of the reaction. Instead, the time until the As ${ }^{I I I}$ concentration in solution is half of the initial value $\left(t_{1 / 2}\right)$ could be used. The benefit of this approach is that a model fit is not assumed. The data is not fit to a rate law that implicitly assumes that As ${ }^{\text {III }}$ removal is kinetically limited. As a result, $t_{1 / 2}$ would not yield mechanistic information, but would give a basis for comparison between experimental conditions. Additionally, the metric can be estimated from existing rate constants if the rate law was fit well. For example, if the first order model fits the data well without an error term, $t_{1 / 2}$ is equivalent to the half-life, $\ln (2) / k$. Using multiple metrics to describe the data is a good way to begin to develop an overall picture of the reaction, without calculating sorption and desorption rates. Alternatively, an understanding of the full reaction mechanism could yield meaningful kinetic information by allowing for determination of the rates in Figure 3.

\section{Reaction Mechanism}

Hypotheses about the reaction mechanism have evolved over the past four decades, keeping pace with new experimental and analytical methods. Early speculation attributed the formation of a passivating $\mathrm{Mn}^{\mathrm{II}}-\mathrm{As}^{\mathrm{V}}$ complex to the second, slower reaction rate, and the lack of $\mathrm{Mn}^{\mathrm{II}}$ release into solution [36,71]. Moore et al. (1990) observed the formation of a gel after 4 hours of reaction. The gel is reported to have an As/Mn ratio between 0.9 and 1, which would be expected of krautite, a $\mathrm{Mn}^{\mathrm{II}}-\mathrm{As} \mathrm{V}$ mineral [71]. However, the distance between $\mathrm{As}$ and $\mathrm{Mn}$ atoms on reacted $\mathrm{Mn}$ oxide is about $8 \%$ shorter than the theoretical distance for $\mathrm{Mn}_{2}(\mathrm{OH})_{8}\left(\mathrm{AsO}_{4}\right)^{7-}$, the proposed $\mathrm{Mn}^{\mathrm{II}}-\mathrm{As}^{\mathrm{V}}$ complex [70]. Even if krautite was precipitating in experimental conditions, the formation requires As concentrations much higher than would be found in most natural systems. The solubility constant $\left(\mathrm{K}_{\mathrm{sp}}\right)$ for krautite is 0.63 [36]. For a system at $\mathrm{pH} 7$, with the World Health Organization (WHO) limit of $10 \mathrm{ppb}$ As, the $\mathrm{Mn}^{\mathrm{II}}$ concentration in solution would be $1.2 \mathrm{M}$ at equilibrium. Since this Mn concentration is significantly higher than typical environmental values $\left(\sim 10^{-5} \mathrm{M}\right)$, it is unlikely that a significant amount of krautite forms, other than in concentrated experimental conditions [83].

The next attempts at defining the reaction scheme focused on the role of $\mathrm{Mn}^{\mathrm{III}}$. Nesbitt et al. (1997) proposed that the oxidation of As occurs in two steps, with $\mathrm{Mn}^{\mathrm{III}}$ as an intermediate [35]. $\mathrm{Mn}^{\mathrm{III}}$ is thought to create a film on the solid surface as $\mathrm{MnOOH}^{*}$. The $\mathrm{Mn}^{\mathrm{III}}$ concentration reaches a maximum, then decreases as it oxidizes additional As ${ }^{\mathrm{III}}$. This mechanism is theoretically supported by X-ray photoelectron spectroscopy (XPS) and by reanalysis of batch experiments using $\delta-\mathrm{MnO}_{2}$ performed by Scott and Morgan (1995) [34]. $\mathrm{Mn}^{\mathrm{III}}$ concentrations from the batch experiments were calculated by closing the charge balance in the aqueous phase using $\mathrm{Mn}^{\mathrm{III}}$, rather than measuring the proposed intermediate directly. This approach assumes that all the $\mathrm{Mn}^{\mathrm{II}}$ formed is released into 
solution, not sorbed to the solid surface. However, advances in solid state characterization have shown that $\mathrm{Mn}^{\mathrm{II}}$ sorbs to the solid, both on edge and vacancy sites [36]. This disconnect implies that although two one-electron transfers by $\mathrm{Mn}^{\mathrm{III}}$ may play a role in the overall reaction mechanism, desorption is another rate-limiting step.

The predominant redox reactions can be determined by the aqueous $\mathrm{Mn}^{\mathrm{II}} / \mathrm{As}^{\mathrm{V}}$ ratio for various reaction conditions. If $\mathrm{As}^{\mathrm{III}}$ oxidation occurs by two one-electron transfers (e.g., from $2 \mathrm{Mn}^{\mathrm{III}}$ to $2 \mathrm{Mn}^{\mathrm{II}}$ ), the ratio would be 2. If $\mathrm{Mn}^{\mathrm{IV}}$ is reduced directly to $\mathrm{Mn}^{\mathrm{II}}$, one $\mathrm{Mn}^{\mathrm{II}}$ atom is produced per atom of $\mathrm{As}^{\mathrm{V}}$ product, and the ratio would be 1 . Theoretically, this ratio must be between 1 and 2 , assuming all reaction products are in solution. The $\mathrm{Mn}^{\mathrm{II}} / \mathrm{As}^{\mathrm{V}}$ ratio can be predicted as a function of initial AMON. Pure $\mathrm{MnO}_{2}$ would have a ratio of 1 , and $\mathrm{Mn}$ oxides with $\mathrm{Mn}^{\mathrm{III}}$ substitutions would have higher ratios. Assuming a Mn oxide is made of only $\mathrm{Mn}^{\mathrm{III}}$ and $\mathrm{Mn}^{\mathrm{IV}}$, and the presence of $\mathrm{Mn}^{\mathrm{II}}$ does not affect the reaction, the $\mathrm{Mn}^{\mathrm{II}} / \mathrm{As}^{\mathrm{V}}$ ratio is given by Equation (6).

$$
\left(\frac{\mathrm{Mn}(\mathrm{II})}{\mathrm{As}(\mathrm{V})}\right)_{\mathrm{aq}}=\frac{1}{0.5(4-\mathrm{AOS})+(\mathrm{AOS}-3)}
$$

However, under most reaction conditions, the ratio ranges from 0 to 2 because transport of Mn away from the solid surface is slower than transport of $\mathrm{As}^{\mathrm{V}}$ [34]. Nesbitt et al. (1997) refers to $\mathrm{Mn}^{\mathrm{II}} / \mathrm{As}^{\mathrm{V}}$ ratios significantly greater than 1, reported in Scott and Morgan (1995), as evidence for the $\mathrm{Mn}^{\mathrm{III}}$ intermediate [35]. Strangely, the ratios reported in Scott and Morgan (1995) reached a maximum of 0.93 , and not above 1 [34]. In stirred-flow experiments with $\delta-\mathrm{MnO}_{2}$, the $\mathrm{Mn}^{\mathrm{II}} / \mathrm{As}^{\mathrm{V}}$ ratio is 1.15 during the slower phase of the reaction [37]. A higher ratio in stirred-flow experiments than in batch experiments is expected because the reaction products are removed from the system as they form. As a result, $\mathrm{Mn}^{\mathrm{II}}$ remains in the aqueous phase, rather than sorbed to the solid surface. According to Equation (6), ratios of 0.93 and 1.15 correspond to AMONs of 4.15 and 3.74, respectively, rather than 3.95, as expected [37]. Thus, the mechanism is more complicated than the mechanism represented by Equation (6).

The mechanism is likely a combination of several different electron transfer and sorption steps. Equations (7)-(10) describe the potential rate limiting steps, where $\mathrm{Mn}^{\mathrm{III}, \mathrm{IV}} \mathrm{O}_{\mathrm{x}}$ represents a general $\mathrm{Mn}$ oxide and $\equiv$ represents sorption to the Mn oxide. The reactions describe As ${ }^{\mathrm{III}}$ sorption and desorption on the $\mathrm{Mn}$ oxide, electron transfer, $\mathrm{As}^{\mathrm{V}}$ sorption and desorption, and $\mathrm{Mn}^{\mathrm{II}}$ sorption and desorption, in the order presented below.

$$
\begin{aligned}
& \mathrm{As}^{\mathrm{III}}(\mathrm{aq})+\mathrm{Mn}^{\mathrm{III}, \mathrm{IV}} \mathrm{O}_{\mathrm{x}} \underset{k_{-1}}{\stackrel{k_{1}}{\leftrightarrow}} \mathrm{Mn}^{\mathrm{III}, \mathrm{IV}} \mathrm{O}_{\mathrm{x}} \equiv \mathrm{As}^{\mathrm{III}} \\
& \mathrm{Mn}^{\mathrm{III}, \mathrm{IV}} \mathrm{O}_{\mathrm{x}} \equiv \mathrm{As}^{\mathrm{III}} \stackrel{k_{2}}{\rightarrow} \mathrm{Mn}^{\mathrm{III}, \mathrm{IV}} \mathrm{O}_{\mathrm{x}} \equiv \mathrm{As}^{\mathrm{V}}+\mathrm{Mn}^{\mathrm{III}, \mathrm{IV}} \mathrm{O}_{\mathrm{x}} \equiv \mathrm{Mn}^{\mathrm{II}} \\
& \mathrm{Mn}^{\mathrm{III}, \mathrm{IV}} \mathrm{O}_{\mathrm{x}} \equiv \mathrm{As}^{\mathrm{V}} \underset{k_{-3}}{\stackrel{k_{3}}{\leftrightarrow}} \mathrm{Mn}^{\mathrm{IIII}, \mathrm{IV}} \mathrm{O}_{\mathrm{x}}+\mathrm{As}^{\mathrm{V}}(\mathrm{aq}) \\
& \mathrm{Mn}^{\mathrm{III}, \mathrm{IV}} \mathrm{O}_{\mathrm{x}} \equiv \mathrm{Mn}^{\mathrm{II}} \stackrel{k_{4}}{\leftrightarrow} \mathrm{Mn}^{\mathrm{III}, \mathrm{IV}}+\mathrm{Mn}^{\mathrm{II}}(\mathrm{aq}) \\
& k_{-4}
\end{aligned}
$$

These reactions happen in conjunction with both comproportionation, where $\mathrm{Mn}^{\mathrm{II}}$ and $\mathrm{Mn}^{\mathrm{IV}}$ form two $\mathrm{Mn}^{\mathrm{III}}$, and disproportionation, where two $\mathrm{Mn}^{\mathrm{III}}$ form $\mathrm{Mn}^{\mathrm{II}}$ and $\mathrm{Mn}^{\mathrm{IV}}[37,44,84-86]$. As discussed above, the electron transfer rate is time-dependent, likely due to differences in reactivity between $\mathrm{Mn}^{\mathrm{IV}}$ 
and $\mathrm{Mn}{ }^{\mathrm{III}}$. Thus, $k_{2}$ changes throughout the reaction, and the electron transfer could be described by two separate reactions, as is done in Figure 3.

The conceptual basis for the sorption steps can be understood by considering the electrostatic forces involved. As the Mn oxide is reductively dissolved, $\mathrm{Mn}^{\mathrm{II}}$ and $\mathrm{Mn}^{\mathrm{III}}$ are produced. Vacancy sites have a strong negative charge, so they sorb positively charged $\mathrm{Mn}^{\mathrm{II}}{ }^{\mathrm{IIII}}$. Meanwhile, the oxyanion formed by $\mathrm{As}^{\mathrm{V}}$ sorbs to edge sites. Once the vacancy sites are filled, $\mathrm{Mn}^{\mathrm{II}}$ competes with $\mathrm{As}^{\mathrm{V}}$ for edge sites. The electron transfer happens at edge sites, so sorbed reaction products passivate the solid surface, slowing the As ${ }^{\mathrm{III}}$ depletion rate [36]. The reaction rate also decreases as comproportionation forms $\mathrm{Mn}^{\mathrm{III}}$, which is less reactive than $\mathrm{Mn}^{\mathrm{IV}}$ [48]. In experimental systems, $\mathrm{As}^{\mathrm{III}}$ oxidation by Mn oxides is complicated by sorption, desorption, and electron transfer between Mn species. In environmental systems, the $\mathrm{pH}$, temperature, presence of other oxides and other ions, and various other factors further complicate our understanding of $\mathrm{As}{ }^{\mathrm{III}}$ depletion in solution.

\section{Environmental Factors Affecting As Oxidation by Mn Oxides}

The study of several environmental factors in isolated controlled laboratory experiments has led to a clear understanding of the potential impact of these factors in the subsurface. Figure 5 depicts the expected effect of $\mathrm{pH}$, temperature, presence of competitive ions, and presence of Fe oxides on As ${ }^{\mathrm{III}}$ depletion by Mn oxides.

\section{1. $p H$}

The system $\mathrm{pH}$ affects the Mn oxide surface properties and As protonation state, changing the relative impact of different steps in the reaction mechanism and altering the kinetic rate $[50,87]$. Synthetic Mn oxides encompass a wide range of average PZCs. The reported range for the PZC of the birnessite group is 1.5-3.5, 2.8-4.6 for minerals in the hollandite group, and 6.4-7.3 for pyrolusite (Figure 6) [88]. Biogenic Mn oxides typically have higher PZCs than synthetic birnessite [39]. A high temperature synthesis method can be used to create birnessite nanosheets with a PZC less than 0.36 [72]. As the $\mathrm{pH}$ of the system increases, the surface of the Mn oxide becomes more negative, resulting in increased sorption of $\mathrm{Mn}^{\mathrm{II}}$ and $\mathrm{Mn}^{\mathrm{III}}$ to the solid surface (Figure 5b,c) [50]. The PZC of edge sites is expected to be higher than that of vacancies [89]. As a result, there is less electrostatic repulsion at edge sites by negatively charged As oxyanions, compared to at vacancies. This confirms previous work indicating that As sorption occurs at edge sites, while $\mathrm{Mn}^{\mathrm{II}}{ }^{\mathrm{IIII}}$ sorption occurs at vacancies [36].

Both inorganic As species are triprotic oxyanions. The fractions of each As species in a given protonation state are shown in Figure 5. Pentavalent As has $\mathrm{pK}_{\mathrm{a}}$ values of 2.2, 6.9, and 11.5, therefore, $\mathrm{H}_{2} \mathrm{AsO}_{4}{ }^{-}$or $\mathrm{HAsO}_{4}{ }^{2-}$ predominate in neutral $\mathrm{pH}$ natural waters [90]. Trivalent As has $\mathrm{pK}_{\mathrm{a}}$ values of 9.2, 12.1, and 13.4, and $\mathrm{H}_{3} \mathrm{AsO}_{3}$ predominates at circumneutral $\mathrm{pH}$ [90]. The lack of charge allows $\mathrm{As}^{\mathrm{III}}$ to diffuse faster than $\mathrm{As}^{\mathrm{V}}$ to the negatively-charged $\mathrm{Mn}$ oxide surface. Since $\mathrm{As}{ }^{\mathrm{III}}$ is oxidized at this surface, the negative charge of $\mathrm{As}^{\mathrm{V}}$ and the $\mathrm{Mn}$ oxide do not repel as they would if $\mathrm{As}^{\mathrm{V}}$ was added to solution directly [38]. This may contribute to the greater sorption capacity of $\mathrm{As}^{\mathrm{V}}$ on $\mathrm{Mn}$ oxides when added as $\mathrm{As}^{\mathrm{III}}$ than when added as $\mathrm{As}^{\mathrm{V}}$ [38]. More recently, the difference in sorption capacities has been associated with a surface alteration during the electron transfer [70]. In the case of birnessite and cryptomelane, the As ${ }^{\mathrm{III}}$ depletion rate of birnessite is greater than that of cryptomelane, despite the larger surface area of cryptomelane [38]. This is attributed to the higher average PZC of cryptomelane, which sorbs $\mathrm{As}^{\mathrm{V}}$ to a larger extent than birnessite [38]. At circumneutral $\mathrm{pH}$, the cryptomelane surface has an overall less negative charge than birnessite, and can thus sorb more As. Sorbed $\mathrm{As}^{\mathrm{V}}$ competes with As ${ }^{\mathrm{III}}$ for edge sites, preventing As ${ }^{\mathrm{III}}$ oxidation. 
(a)

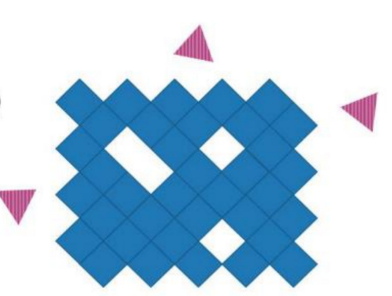

UNREACTED

(c)

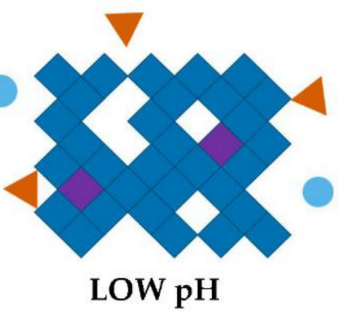

(e)

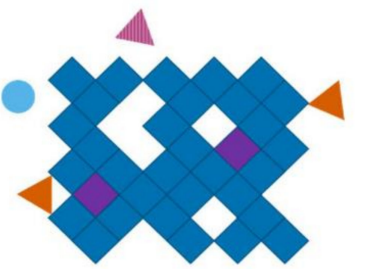

LOW TEMPERATURE (b)

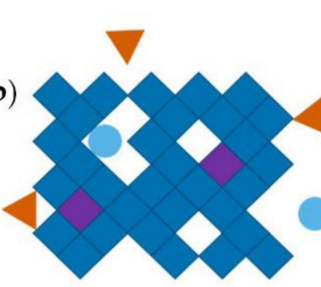

REACTED

(d)

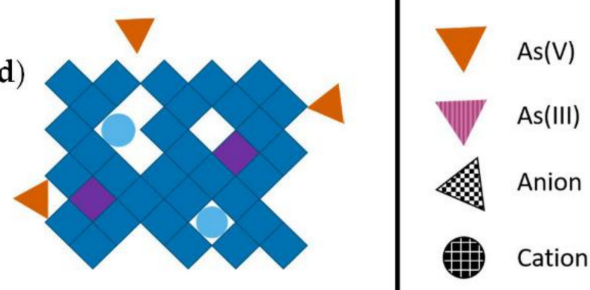

HIGH pH

(f)

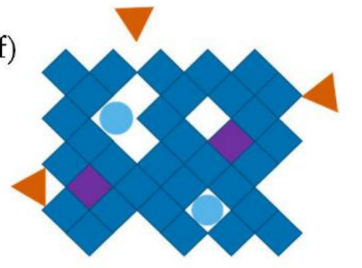

HIGH TEMPERATURE (g)

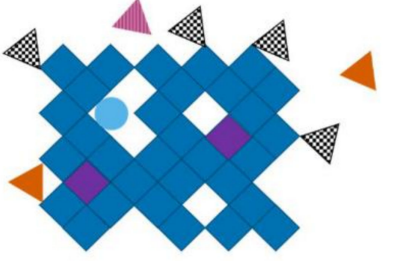

ANIONS PRESENT (h)

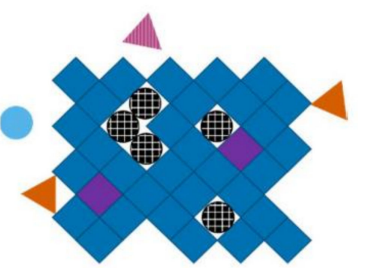

CATIONS PRESENT

(i)

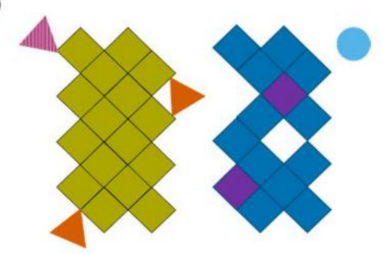

IRON OXIDES PRESENT

Figure 5. Expected impact of environmental factors on As oxidation by Mn oxides (a) relative to the reaction of a pure As, Mn oxide system at $25^{\circ} \mathrm{C}$, and circumneutral $\mathrm{pH}(\mathbf{b})$, as projected from above a phyllomanganate layer. As ${ }^{\mathrm{III}} \mathrm{V}$ adsorb to edge sites while $\mathrm{Mn}^{\mathrm{II}}$ sorbs above vacancies. $\mathrm{Mn}^{\mathrm{III}}$ replaces $\mathrm{Mn}{ }^{\mathrm{IV}}$ in the reacted oxide. Low $\mathrm{pH}(\mathbf{c})$ and temperature (e) inhibit $\mathrm{Mn}^{\mathrm{II}}$ sorption; high $\mathrm{pH}(\mathbf{d})$ and temperature (f) enhance $\mathrm{Mn}^{\mathrm{II}}$ sorption. The oxidation rate is lower at lower temperatures. Anions (e.g., $\left.\mathrm{PO}_{4}{ }^{3-}\right)(\mathrm{g})$ and surface cations (e.g., $\left.\mathrm{Pb}^{\mathrm{II}}, \mathrm{Co}^{\mathrm{II}}\right)(\mathrm{f})$ sorb to edge and above vacancy sites, respectively, impeding sorption and oxidation of As ${ }^{\mathrm{III}}$. As ${ }^{\mathrm{III}, \mathrm{V}}$ preferentially adsorb to Fe oxides, while As ${ }^{I I I}$ is oxidized on the Mn oxide surface (i). 


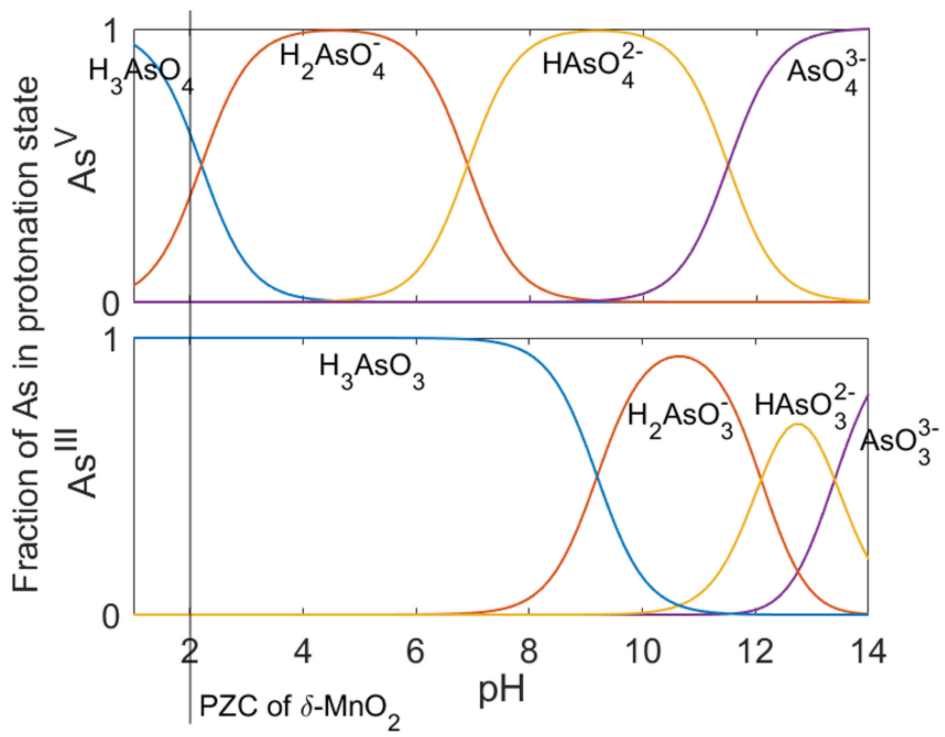

Figure 6. Protonation state of $\mathrm{As}^{\mathrm{III}}$ and $\mathrm{As}^{\mathrm{V}}$ as a function of $\mathrm{pH}$ compared to the average PZC of $\delta-\mathrm{MnO}_{2}$. As $\mathrm{pH}$ increases, the Mn oxide surface and the $\mathrm{As}{ }^{\mathrm{III}}$ and $\mathrm{As}{ }^{\mathrm{V}}$ oxyanions have a more negative charge.

The electron transfer process between $\mathrm{Mn}$ and $\mathrm{As}$ is also affected by solution $\mathrm{pH}$. The $\mathrm{pH}$-dependent redox potentials of the $\mathrm{As}^{\mathrm{III}}$ and $\mathrm{Mn}^{\mathrm{IV}}$ reaction indicate that the As ${ }^{\mathrm{III}}$ oxidation capacity of Mn oxides is not constant with respect to $\mathrm{pH}$ (Figure 7). However, analysis of the redox potentials indicates that essentially all $\mathrm{As}^{\mathrm{III}}$ is oxidized at equilibrium. In extremely acidic conditions (below $\mathrm{pH}$ 2), the redox reaction is given by Equation (11).

$$
\mathrm{MnO}_{2}(\mathrm{~s})+\mathrm{H}_{3} \mathrm{AsO}_{3}(\mathrm{aq})+2 \mathrm{H}^{+}(\mathrm{aq}) \leftrightarrow \mathrm{Mn}^{2+}(\mathrm{aq})+\mathrm{H}_{3} \mathrm{AsO}_{4}(\mathrm{aq})+\mathrm{H}_{2} \mathrm{O}(\mathrm{l})
$$

Arsenic

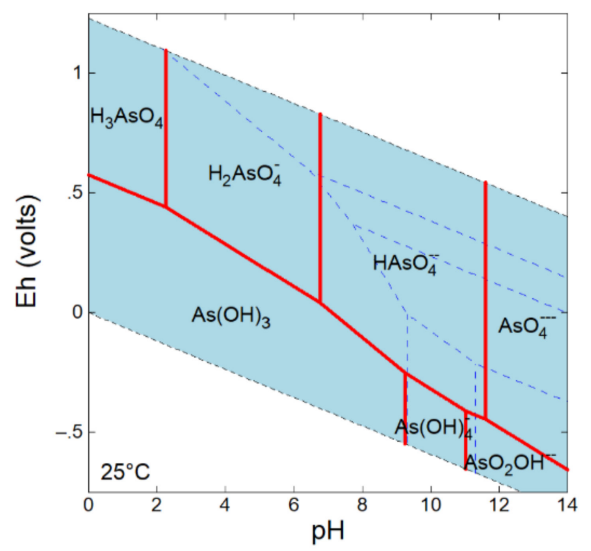

Manganese

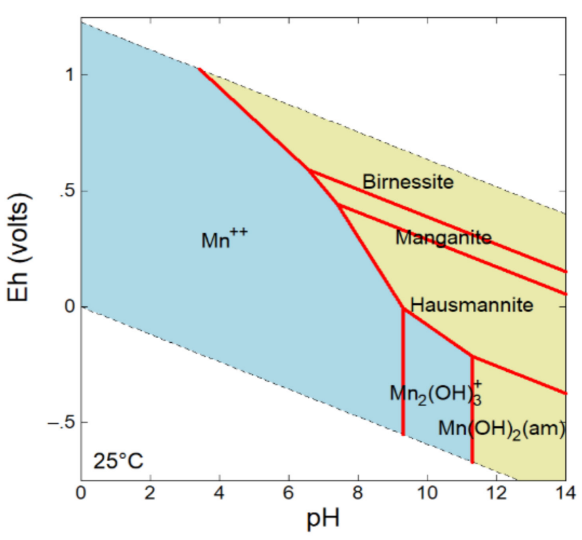

Figure 7. Pourbaix diagrams for $10 \mathrm{ppb}$ As and $50 \mathrm{ppb} \mathrm{Mn}$ at $25^{\circ} \mathrm{C}$ and $1 \mathrm{~atm}$.

Assuming the activities of solids and liquids are in unity, and making use of the redox half reactions that make up Equation (11), with the Nernst equation, gives the equilibrium constant in Equation (12).

$$
\mathrm{K}=\frac{\left[\mathrm{Mn}^{2+}\right]\left[\mathrm{H}_{3} \mathrm{AsO}_{4}\right]}{\left[\mathrm{H}_{3} \mathrm{AsO}_{3}\right]\left[\mathrm{H}^{+}\right]^{2}}=10^{22.0}
$$


This large $\mathrm{K}$ value demonstrates that even at low $\mathrm{pH}$, if equilibrium is established, almost all of the As exists as $\mathrm{As}^{\mathrm{V}}$. A similar theoretical analysis in basic conditions leads to the same conclusion. However, experimental results determining the oxidation capacity of different Mn oxides indicate that this may not always be the case. Solutions of As ${ }^{\mathrm{III}}$ and suspended Mn oxides were allowed to reach presumed chemical equilibrium [49]. Birnessite exhibits a minimum amount of $\mathrm{As}^{\mathrm{III}}$ oxidized at $\mathrm{pH} 6.3$, while cryptomelane and hausmannite appear to oxidize increasing amounts of $\mathrm{As}^{\mathrm{III}}$ as the $\mathrm{pH}$ increases from 2 to 11.5 [49]. However, none of the reactions oxidize all of the $\mathrm{As}^{\mathrm{III}}$, even though the thermodynamic calculations above dictate that they should [49]. From these experiments and calculations, it is evident that $\mathrm{As}{ }^{\mathrm{III}}$ oxidation by Mn oxides may be kinetically limited and not thermodynamically limited.

Since thermodynamic trends do not always translate to kinetic trends, the kinetics of the oxidation reaction require experimental investigation. Fischel et al. (2015) performed batch reactions of acid birnessite with $\mathrm{As}^{\mathrm{III}}$, and calculated observed first order rate constants [50]. Experiments at $\mathrm{pH} 4.2$, 7.2 , and 9.0 result in rate constants of $0.433,0.133$, and $0.246 \mathrm{~s}^{-1}$, respectively. This suggests that the kinetics of the reaction may exhibit a minimum rate constant at circumneutral $\mathrm{pH}$ because the rate constant at $\mathrm{pH} 7.2$ is lower than that of the higher and lower $\mathrm{pH}$ values. Kinetic modeling using the reactions and rate constants presented in Equations (7)-(10) indicate that as $\mathrm{pH}$ increases from 4 to 8.2, so do the rates of $\mathrm{As}^{\mathrm{V}}$ adsorption $\left(5 \times 10^{6}-8 \times 10^{9} \mathrm{M}^{-2} \mathrm{~s}^{-1}\right)$, $\mathrm{Mn}^{\mathrm{II}}$ desorption $\left(2.5 \times 10^{6}-1.5 \times 10^{10}\right.$ $\mathrm{M}^{-2} \mathrm{~s}^{-1}$ ), and $\mathrm{Mn}^{\mathrm{II}}$ adsorption (5-12 $\mathrm{M}^{-1} \mathrm{~s}^{-1}$ ), while other rates remain the same [87]. This seems inconsistent with our understanding of $\mathrm{pH}$, and could possibly be explained by an underspecified system with too many fitting parameters. Further experiments at intermediate $\mathrm{pH}$ values are needed to more accurately determine the relationship between $\mathrm{pH}$ and reaction rate.

\subsection{Temperature}

As with $\mathrm{pH}$, the impact of temperature has been studied over a small range, but the results are somewhat inconclusive. Existing investigations into the kinetics of As oxidation by Mn oxides are limited to $25 \pm 20^{\circ} \mathrm{C}[38,50,87]$. Fischel et al. (2015) reports first order observed rate constants of $0.0026 \mathrm{~s}^{-1}\left(10^{\circ} \mathrm{C}\right), 0.0027 \mathrm{~s}^{-1}\left(25^{\circ} \mathrm{C}\right)$, and $0.0037 \mathrm{~s}^{-1}\left(40^{\circ} \mathrm{C}\right)$ for $\mathrm{As}{ }^{\mathrm{III}}$ oxidation by $\delta-\mathrm{MnO}_{2}$ [50]. Scott (1991) modeled the overall As ${ }^{I I I}$ removal reaction using rate constants as described by Equations (7)-(10). As temperature increases from 15 to $35^{\circ} \mathrm{C}$, the rate constants for As ${ }^{\mathrm{III}}$ adsorption $\left(2.5-7.5 \mathrm{M}^{-1}\right.$ $\left.\mathrm{s}^{-1}\right)$, $\mathrm{Mn}^{\mathrm{II}}$ adsorption $\left(2.5 \times 10^{6}-9 \times 10^{6} \mathrm{M}^{-2} \mathrm{~s}^{-1}\right)$, and $\mathrm{Mn}^{\mathrm{II}}$ desorption $\left(2.5-35 \mathrm{M}^{-1} \mathrm{~s}^{-1}\right)$ increases. The As to Mn electron transfer decreases $\left(0.03-0.015 \mathrm{~s}^{-1}\right)$ as temperature increases, contrary to what is expected in chemical reactions [87]. Enhanced $\mathrm{Mn}^{\mathrm{II}}$ adsorption is attributed to the decrease of the $\mathrm{Mn}$ oxide PZC with increasing temperature [91]. As a result, the solid surface's negative charge increases as temperature increases, resulting in increased $\mathrm{Mn}^{\mathrm{II}}$ sorption. While PZC does decrease with increasing temperature, we do not expect the change over a small temperature range to greatly effect sorption, because an increase of $15^{\circ} \mathrm{C}$ is associated with a PZC decrease of only up to $0.45 \mathrm{pH}$ units $[92,93]$. At higher temperatures, the combination of a decrease in removal capacity due to enhanced $\mathrm{Mn}^{\mathrm{II}}$ sorption, and an increase in reaction rate due to increased internal energy, results in a net increase in overall reaction rate (Figure 5e,f) [50].

\subsection{Other Oxides}

Mn oxides are just one component of the soil or sediment matrix that impact contaminant fate. Iron and aluminum (Al) oxides, as well as clays and organic matter, are known to have high sorption capacities for As [94-96]. Numerous studies have reinforced our understanding of the impact of combinations of Fe and $\mathrm{Al}$ oxides in both natural and synthetic systems. Due to their high sorption capacities and environmental abundance, the impact of Fe oxides has been especially well investigated. Goethite, $\alpha-\mathrm{FeOOH}$, is commonly used as the synthetic analogue of environmentally relevant $\mathrm{Fe}$ oxides, and has a PZC of $9.4[97,98]$. In systems with $\mathrm{As}, \mathrm{Fe}$ oxides, and $\mathrm{Al}$ oxides, $\mathrm{As}{ }^{\mathrm{V}}$ adsorbs to both metal oxides, while As ${ }^{\text {III }}$ preferentially adsorbs to Fe oxides [99]. This trend exists in systems of 
mixed Fe oxides and $\mathrm{Al}$ oxides as well as coprecipitated $\mathrm{Al}$, Fe oxides $[99,100]$. However, $\mathrm{As}{ }^{\mathrm{III}}$ binds to Fe oxides in weak complexes (outer-sphere, bi-nuclear bidentate, and monodentate) that are easily desorbed when environmental conditions change [101-109]. Weak tridentate complexes are possible when As $s^{\mathrm{III}}$ sorbs to magnetite, a type of Fe oxide [110]. As ${ }^{\mathrm{III}}$ adsorbs on Fe oxides to a greater extent than $\mathrm{As}^{\mathrm{V}}$ [111-115].

The As ${ }^{\mathrm{III}}$ depletion capacity of a Mn and Fe oxide system is higher than that of either oxide alone $[49,74,116-118]$. This phenomenon is the product of two opposing mechanisms. In one, $\mathrm{As}{ }^{\mathrm{III}}$ is oxidized to $\mathrm{As}^{\mathrm{V}}$ by the Mn oxides. Some of the $\mathrm{As}^{\mathrm{V}}$ is released by the Mn oxide then sorbs to the Fe oxide, decreasing passivation of the Mn oxide surface, resulting in further As ${ }^{\mathrm{III}}$ oxidation (Figure 5i). At the same time, the Fe oxides also sorb As ${ }^{\mathrm{III}}$, preventing As ${ }^{\mathrm{III}}$ oxidation on the Mn oxide surface [74]. Ying et al. (2012) confirmed this using a reactor with birnessite and goethite separated by a $0.1 \mu \mathrm{m}$ polycarbonate filter that allowed for As transport [114].

Kinetic analysis of As removal in multiple oxide systems is inconclusive. Oscarson et al. (1983) calculated lower observed first order rate constant for $\mathrm{Fe}$ and $\mathrm{Al}$ oxide coated Mn oxides than for pure Mn oxides [119]. More recently, Parikh et al. (2010) found little impact of $\alpha-\mathrm{FeOOH}$ on the initial oxidation rate of $\delta-\mathrm{MnO}_{2}$ in $\mathrm{As}^{\mathrm{III}}$ batch reactions [74]. The depletion rate of aqueous $\mathrm{As}{ }^{\mathrm{III}}$ is expected to change for different metal oxide surface site concentrations according to Equation (13). As with $\mathrm{Mn}$ reactive sites, $\mathrm{Fe}$ and $\mathrm{Al}$ oxides have different reaction orders due to differences in sorption affinities.

$$
\mathrm{r}_{\mathrm{As}(\mathrm{III})}=\frac{\mathrm{d}[\mathrm{As}(\mathrm{III})]}{\mathrm{dt}}=-k\left[\mathrm{As}^{3+}\right]^{\alpha}\left[>\mathrm{Mn}^{4+}\right]^{\beta}\left[>\mathrm{Mn}^{3+}\right]^{\gamma}\left\{\mathrm{H}^{+}\right\}^{\epsilon}\left[>\mathrm{Fe}^{3+}\right]^{\zeta}\left[>\mathrm{Al}^{3+}\right]^{\eta}
$$

Studying combined Fe and Mn oxide systems allows for exploitation of the natural heterogeneity of soils and provides opportunities to engineer solids for As removal. Samples with natural Fe and Mn oxide mixtures have demonstrated high As removal capacity, confirming the trends observed with synthetic Mn oxides [120-122]. Recent work on engineered Fe-Mn binary oxides have been successful in removing As from solution $[115,123]$. These strategies include pure Fe-Mn binary oxides, magnetic nanoparticles (Mag-Fe-Mn), and Fe-Mn binary oxide impregnated chitosan [124,125]. Engineered particles have also proved effective in removing aromatic organoarsenic compounds [126].

\subsection{Competitive Ions}

For a comprehensive understanding of $\mathrm{As}{ }^{\mathrm{III}}$ oxidation by Mn oxides, it is important to incorporate the role of aqueous cations and anions. Ions may co-precipitate with $\mathrm{Mn}$ oxides or interact with existing Mn oxides. These interactions can be further divided into systems where the ions are present before the As enters (e.g., in allogenic or anthropogenic As contamination) or systems where As and other ions are added simultaneously to Mn oxides (e.g., in water treatment applications). The fate of As in systems with other ions depends on the source of the solutes.

Phosphate is prevalent in environmental systems because of its use as a fertilizer that can leach into groundwater [127]. The phosphate ion $\left(\mathrm{PO}_{4}{ }^{3-}\right)$ has a similar structure to arsenate. Furthermore, the $\mathrm{pK}_{\mathrm{a}} \mathrm{s}$ of phosphoric acid are similar to those of $\mathrm{H}_{3} \mathrm{AsO}_{4}$. They are 2.2, 7.2, 12.3 for phosphoric acid $\left(\mathrm{H}_{3} \mathrm{PO}_{4}\right)$ compared with $2.2,6.9$, and 11.5 for $\mathrm{H}_{3} \mathrm{AsO}_{4}$. As a result, phosphate competes for reactive sites with $\mathrm{As}^{\mathrm{V}}$, reducing $\mathrm{As}^{\mathrm{V}}$ production, as well as total As sorption (Figure $5 \mathrm{~g}$ ). In systems with lower phosphate concentrations than As concentrations, the initial As ${ }^{\mathrm{III}}$ depletion rate is not impacted by the presence of sulfate or phosphate [74,77]. In a reaction where the phosphate concentration was equal to As concentration, the slope of the initial reaction rate $\left(\mathrm{m}_{30 \mathrm{~s}}\right)$ was 0.02 with phosphate, compared to 0.10 without phosphate [74].

Divalent cations are of interest in As oxidation by Mn oxides, due to their similarity to $\mathrm{Mn}^{\mathrm{II}}$. The presence of $\mathrm{Mn}^{\mathrm{II}}, \mathrm{Fe}(\mathrm{II})$, calcium (Ca(II)), cobalt (Co.(II)), nickel (Ni(II)), zinc ( $\mathrm{Zn}(\mathrm{II})$ ), and lead $(\mathrm{Pb}(\mathrm{II}))$ decrease the oxidation rate of $\mathrm{As}^{\mathrm{III}}$ by Mn oxides [34,55,64,67,77,116,128]. With the exception of $\mathrm{Pb}$, these metals are all in the fourth row of the periodic table, so they have similar electron configurations and atomic radii. Additionally, all but $\mathrm{Ca}$ and $\mathrm{Pb}$ have metal-oxygen bond distances 
between 2.06 and $2.20 \AA$ [129]. As with the addition of metal oxides, a reaction rate with a factor for competitive ions can be added to the rate law. For example, Ca affects As oxidation by Mn oxides with a reaction order of -0.2 [77]. In the study of $\mathrm{Pb}$ (II) and $\mathrm{Zn}$ (II), the addition of metals decreased the initial As ${ }^{\mathrm{III}}$ depletion rate, but resulted in equal or greater extents of As ${ }^{\mathrm{III}}$ removal. The initial rate decrease is attributed to site blockage, while the increase in oxidation capacity can be explained by decreased overall electrostatic repulsion from the metal cations, enhancing oxyanion As sorption [55].

In batch experiments with biogenic Mn oxides, the $\mathrm{As}{ }^{\mathrm{III}}$ oxidation rate decreased when metal ions were added. The reduction of oxidation rate was dependent on the ion and followed the order $\mathrm{Mn}^{2+}>\mathrm{Co}^{2+} \approx \mathrm{Ni}^{2+}>\mathrm{Zn}^{2+}$, with first order rate constants $0.071 \mathrm{~h}^{-1}, 0.091 \mathrm{~h}^{-1}, 0.128 \mathrm{~h}^{-1}, 0.215 \mathrm{~h}^{-1}$, respectively. The addition of metal ions increased the total As adsorbed significantly by suppressing the charge repulsion between the negatively charged mineral surface and As oxyanions. The adsorption was highest for $\mathrm{Zn}^{2+}(99.5 \%)$, then $\mathrm{Ni}^{2+}$ and $\mathrm{Co}^{2+}\left(38.3 \%\right.$ and $39.5 \%$, respectively), then $\mathrm{Mn}^{2+}(25.9 \%)$, compared to $4.3 \%$ for no metal ion addition [69]. However, different Mn oxide minerals have different affinities for different ions. A biogenic Mn oxide produced by Mn oxidizing fungus KR21-2 had sorption affinities ranking $\mathrm{Co}^{2+}>\mathrm{Zn}^{2+}>\mathrm{Ni}^{2+}$, while that of synthetic $\gamma-\mathrm{MnO}_{2}$ was $\mathrm{Zn}^{2+}>\mathrm{Co}^{2+}>$ $\mathrm{Ni}^{2+}$ [130]. It is clear that divalent cations decrease the rate of As oxidation by Mn oxides, but the extent of the decrease is dependent on the specific mineral and cation (Figure 5h).

\subsection{Other Factors}

Investigations into the impact of bacteria, sunlight, and reactive oxygen species round out the existing literature on environmental factors in $\mathrm{As}^{\mathrm{III}}$ oxidation by Mn oxides. Microorganisms can aid in As ${ }^{\text {III }}$ oxidation by either oxidizing Mn to produce Mn oxides, that in turn, oxidize As ${ }^{\mathrm{III}}$, or oxidize As ${ }^{\mathrm{III}}$ directly [39]. These microorganisms can use As ${ }^{\mathrm{III}}$ as the sole electron donor (chemolithoautotrophic metabolism) or as one of multiple electron donors [131-134]. An As oxidase with associated genes has been identified in A. faecalis, but others may exist [135]. To investigate the effect of As ${ }^{\mathrm{III}}$ oxidizing microbes in the presence of Mn oxides, Parikh et al. (2010) mixed P. fluorescens and A. faecalis with $\mathrm{As}^{\mathrm{III}}$ and $\delta-\mathrm{MnO}_{2}$. In both pretreated experiments and simultaneous additions, the bacteria enhanced passivation, decreasing As ${ }^{\mathrm{III}}$ oxidation and initial reaction rates. This suggests As ${ }^{\mathrm{III}}$ diffusion through the biofilm formed in pretreatment is the rate limiting step [74]. In a similar study with P. fluorescens and A. tumefaciens, Jones et al. (2012) found an additive increase in initial reaction rate with both bacteria and $\delta-\mathrm{MnO}_{2}$, relative to bacteria or $\delta-\mathrm{MnO}_{2}$ alone. The combined bacteria and $\delta-\mathrm{MnO}_{2}$ system has decreased As sorption and increased desorption, implying that the As is sorbed in weak complexes. In batch reactions with only bacteria, the bacteria oxidized $\mathrm{As}{ }^{\mathrm{III}}$ with an observed zero order reaction, and cells did not retain As [66]. The microbial community of an environmental system may greatly impact As oxidation either by inhibiting oxidation due to biofilm formation or by directly enhancing oxidation [136].

The presence of light and oxygen may also impact As ${ }^{\mathrm{III}}$ oxidation by Mn oxides. Shumlas et al. (2016) found that at $\mathrm{pH} 5$, the oxidation reaction is faster in simulated sunlight than in the dark, but the trend did not hold for $\mathrm{pH} 7$ and $\mathrm{pH}$ 9. The effect on overall oxidation capacity is unclear because the reactions were not run until the $\mathrm{As}^{\mathrm{V}}$ concentrations leveled off. The impact of light was consistent for both oxic and anoxic experiments, indicating that elemental oxygen may not play a role in As ${ }^{\text {III }}$ oxidation by Mn oxides on short timescales [137]. While the primary concern of As contamination is in groundwater, where light and oxygen are approximately constant, it is important to consider the laboratory conditions that may impact the environmental relevance of an experiment.

While $\mathrm{Mn}^{\mathrm{II}}$ is oxidized to $\mathrm{Mn}^{\mathrm{III}, \mathrm{IV}}$ in the presence of $\mathrm{O}_{2}$ [138], the impact of $\mathrm{O}_{2}$ on As oxidation by $\mathrm{Mn}$ oxides has not been studied systematically. As a result, some studies on As oxidation by $\mathrm{Mn}$ oxides are performed in an anoxic chambers, but others are not [50,67]. In oxic environments, there may be artificially high oxidation capacities due to the regeneration of Mn oxides throughout the experiment. However, the oxidation rate of $\mathrm{Mn}^{\mathrm{II}}$ in solution is expected to be slower than the oxidation rate of $\mathrm{As}^{\mathrm{III}}$ by $\mathrm{Mn}$ oxides [137]. Additionally, the relative concentration of $\mathrm{O}_{2}$ in the lab compared to 
in oxic sediment is either the same or slightly higher, whereas As and Mn oxide concentrations may be orders of magnitude larger than what is environmentally relevant. As a result, the inconveniences associated with performing experiments on synthetic Mn oxides in anaerobic chambers likely provide little added information concerning As(III) oxidation mechanisms. However, bacteria and other metal oxides are also affected by the presence of $\mathrm{O}_{2}$, so anaerobic natural samples should be kept anaerobic during experiments.

\section{Conclusions}

Studies on As ${ }^{I I I}$ oxidation by Mn oxides cite the potential of Mn oxides to remove As from drinking water and predict subsurface As mobility. This can only happen if the knowledge generated by these studies is carefully parsed to elucidate mechanisms, then applied to in situ remediation methods or ex situ engineered systems. Both of these applications require more rigorous kinetic modeling and solids characterization.

A critical step in developing a comprehensive model As ${ }^{\mathrm{III}}$ depletion by Mn oxides is determining the rate constants involved in the full reaction mechanism (Figure 3). However, this requires on a complete understanding of the individual reaction steps including sorption, desorption, electron transfer between As and Mn, and electron transfer between Mn species. Completing this model is numerically difficult, due in part to rates spanning many orders of magnitude. The model developed by Feng et al. (2018) takes a reductionist approach, and does not incorporate the role of $\mathrm{Mn}^{\mathrm{III}}$ in determining depletion rates [139]. While this approach can predict As(III) oxidation rates in a limited set of conditions, the resulting model parameters lose physical significance, as it does not incorporate steps in the known reaction mechanism. Other modeling approaches use non-kinetic parameters to describe the sorption processes involved. Various surface complexation models (SCM) fit As sorption to Fe oxides [112,140-142] and several divalent cations on Mn oxides [143-148]. For systems that SCMs do not fit well, the CD-MUSIC model has been used $[149,150]$. Reactive transport modeling is also valuable in separating the transport effects from kinetic effects, and fits this system well $[114,143,151]$. More thorough reporting of solid characteristics, specifically PZC and interlayer cations, would greatly improve the quality of experimental data.

Beyond modeling, a better understanding of the impact of temperature and light on As ${ }^{\mathrm{III}}$ oxidation could greatly improve water treatment capabilities. For example, if a certain wavelength of light dramatically increases the As ${ }^{\mathrm{III}}$ oxidation rate by Mn oxides, it could be used to enhance As immobilization in engineered water treatment. In many cases, robust data sets that consider a wide range of conditions (e.g., at many $\mathrm{pH}$ values) are more valuable than studies that briefly consider several unrelated factors. Additionally, frequent sampling and careful data interpretation are critical for a reliable experiment. Our current library of computational methods and both solid and aqueous phase characterization techniques is strong enough to accurately and completely understand As ${ }^{\text {III }}$ depletion by Mn oxides, and move toward applying the information to reduce human exposure to As-contaminated drinking water.

Supplementary Materials: The following are available online at http:/ /www.mdpi.com/2571-8789/2/3/39/s1, Table S1: Compilation of reported observed first order rate constants and experimental conditions.

Funding: This research was made possible by NSF (CBET 1509879) and the Roy F. Weston Wisconsin Distinguished Graduate Fellowship.

Acknowledgments: We thank Madeleine Mathews for her thoughtful comments on an earlier version of this manuscript.

Conflicts of Interest: The authors declare no conflict of interest.

\section{References}

1. Ravenscroft, P.; Brammer, H.; Richards, K. Arsenic Solution: A Global Synthesis; Wiley-Blackwell: Hoboken, NJ, USA, 2009; ISBN 978-1-4051-8601-8. 
2. Hem, J.D. Redox processes at surfaces of manganese oxide and their effects on aqueous metal ions. Chem. Geol. 1978, 21, 199-218. [CrossRef]

3. Borch, T.; Kretzschmar, R.; Kappler, A.; van Cappellen, P.; Ginder-Vogel, M.; Voegelin, A.; Campbell, K. Biogeochemical Redox Processes and their Impact on Contaminant Dynamics. Environ. Sci. Technol. 2010, 44, 15-23. [CrossRef] [PubMed]

4. Remucal, C.K.; Ginder-Vogel, M. A critical review of the reactivity of manganese oxides with organic contaminants. Environ. Sci. Process. Impacts 2014, 16, 1247-1266. [CrossRef] [PubMed]

5. Post, J.E. Manganese oxide minerals: Crystal structures and economic and environmental significance. Proc. Natl. Acad. Sci. USA 1999, 96, 3447-3454. [CrossRef] [PubMed]

6. Nealson, K.H.; Tebo, B.M.; Rosson, R.A. Occurrence and Mechanisms of Microbial Oxidation of Manganese; Academic Press: Cambridge, MA, USA, 1988; Volume 33.

7. Young, L.B.; Harvey, H.H. The Relative Importance of Manganese and Iron-Oxides and Organic-Matter in the Sorption of Trace-Metals by Surficial Lake-Sediments. Geochim. Cosmochim. Acta 1992, 56, 1175-1186. [CrossRef]

8. Toner, B.; Manceau, A.; Webb, S.M.; Sposito, G. Zinc sorption to biogenic hexagonal-birnessite particles within a hydrated bacterial biofilm. Geochim. Cosmochim. Acta 2006, 70, 27-43. [CrossRef]

9. Pang, S.C.; Chin, S.F.; Anderson, M.A. Redox equilibria of iron oxides in aqueous-based magnetite dispersions: Effect of $\mathrm{pH}$ and redox potential. J. Colloid Interface Sci. 2007, 311, 94-101. [CrossRef] [PubMed]

10. McKenzie, R.M. The Synthesis of Birnessite, Cryptomelane, and Some Other Oxides and Hydroxides of Manganese. Mineral. Mag. 1971, 38, 493-502. [CrossRef]

11. McKenzie, R.M. The Manganese Oxides in Soils-A Review. J. Plant Nutr. Soil Sci. 1972, 131, $221-242$. [CrossRef]

12. Balistrieri, L.S.; Chao, T.T. Adsorption of selenium by amourphous iron oxyhydroxide and manganese dioxide. Geochem. Cosmochim. Acta 1990, 54, 739-751. [CrossRef]

13. Scott, M.J.; Morgan, J.J. Reactions at oxide surfaces. 2. Oxidation of Se(IV) by synthetic birnessite. Environ. Sci. Technol. 1996, 30, 1990-1996. [CrossRef]

14. Foster, A.L.; Gordon, E.; Brown, J.; Parks, G.A. X-ray absorption fine structure study of As (V) and Se (IV) sorption complexes on hydrous Mn oxides. Geochim. Cosmochim. Acta 2003, 67, 1937-1953. [CrossRef]

15. Eary, L.E.; Rai, D. Kinetics of chromium (III) oxidation to chromium (VI) by reaction with manganese dioxide. Environ. Sci. Technol. 1987, 21, 1187-1193. [CrossRef]

16. Landrot, G.; Ginder-Vogel, M.; Sparks, D.L. Kinetics of chromium(III) oxidation by manganese(IV) oxides using quick scanning X-ray absorption fine structure spectroscopy (Q-XAFS). Environ. Sci. Technol. 2010, 44, 143-149. [CrossRef] [PubMed]

17. Webb, S.M.; Fuller, C.C.; Tebo, B.M.; Bargar, J.R. Determination of uranyl incorporation into biogenic manganese oxides using X-ray absorption spectroscopy and scattering. Environ. Sci. Technol. 2006, 40, 771-777. [CrossRef] [PubMed]

18. Wang, Z.; Lee, S.-W.; Kapoor, P.; Tebo, B.M.; Giammar, D.E. Uraninite oxidation and dissolution induced by manganese oxide: A redox reaction between two insoluble minerals. Geochim. Cosmochim. Acta 2013, 100, 24-40. [CrossRef]

19. Smedley, P.L.; Kinniburgh, D.G. A review of the source, behaviour and distribution of arsenic in natural waters. Appl. Geochem. 2002, 17, 517-568. [CrossRef]

20. Ahmad, S.A.; Sayed, M.H.S.; Khan, M.H.; Karim, M.N.; Haque, M.A.; Bhuiyan, M.S.A.; Rahman, M.S.; Faruquee, M.H. Sociocultural aspects of arsenicosis in Bangladesh: Community perspective. J. Environ. Sci. Health Part A 2007, 42, 1945-1958. [CrossRef] [PubMed]

21. Argos, M.; Kalra, T.; Rathouz, P.J.; Pierce, B.; Ahsan, H.; Slavkovich, V.M.; Graziano, J.; Islam, T.; Ahmed, A.; Rakibuz-Zaman, M.; et al. Arsenic exposure from drinking water, and all-cause and chronic-disease mortalities in Bangladesh (HEALS): A prospective cohort study. Lancet 2010, 376, 252-258. [CrossRef]

22. Ahmed, K.M.; Bhattacharya, P.; Hasan, M.A.; Akhter, S.H.; Alam, S.M.M.; Bhuyian, M.A.H.; Imam, M.B.; Khan, A.A.; Sracek, O. Arsenic enrichment in groundwater of the alluvial aquifers in Bangladesh: An overview. Appl. Geochem. 2004, 19, 181-200. [CrossRef]

23. Gillispie, E.C.; Andujar, E.; Polizzotto, M.L. Chemical controls on abiotic and biotic release of geogenic arsenic from Pleistocene aquifer sediments to groundwater. Environ. Sci. Process. Impacts 2016, 18, 1090-1103. [CrossRef] [PubMed] 
24. Polizzotto, M.L.; Kocar, B.D.; Benner, S.G.; Sampson, M.; Fendorf, S.E. Near-surface wetland sediments as a source of arsenic release to ground water in Asia. Nature 2008, 454, 505-508. [CrossRef] [PubMed]

25. Ying, S.C.; Schaefer, M.V.; Cock-Esteb, A.; Li, J.; Fendorf, S. Depth Stratification Leads to Distinct Zones of Manganese and Arsenic Contaminated Groundwater. Environ. Sci. Technol. 2017, 51, 8926-8932. [CrossRef] [PubMed]

26. Atsdr, U. Toxicological Profile for Arsenic; Agency for Toxic Substances and Disease Registry, Division of Toxicology: Atlanta, GA, USA, 2007; Volume 24. [CrossRef]

27. De Meyer, C.M.C.; Rodríguez, J.M.; Carpio, E.A.; García, P.A.; Stengel, C.; Berg, M. Arsenic, manganese and aluminum contamination in groundwater resources of Western Amazonia (Peru). Sci. Total Environ. 2017, 607-608, 1437-1450. [CrossRef] [PubMed]

28. Buschmann, J.; Berg, M.; Stengel, C.; Sampson, M.L. Arsenic and manganese contamination of drinking water resources in Cambodia: Coincidence of risk areas with low relief topography. Environ. Sci. Technol. 2007, 41, 2146-2152. [CrossRef] [PubMed]

29. Sthiannopkao, S.; Kim, K.W.; Sotham, S.; Choup, S. Arsenic and manganese in tube well waters of Prey Veng and Kandal Provinces, Cambodia. Appl. Geochem. 2008, 23, 1086-1093. [CrossRef]

30. Bacquart, T.; Frisbie, S.; Mitchell, E.; Grigg, L.; Cole, C.; Small, C.; Sarkar, B. Multiple inorganic toxic substances contaminating the groundwater of Myingyan Township, Myanmar: Arsenic, manganese, fluoride, iron, and uranium. Sci. Total Environ. 2015, 517, 232-245. [CrossRef] [PubMed]

31. Naseem, S.; Mcarthur, J.M. Arsenic and other water-quality issues affecting groundwater, Indus alluvial plain, Pakistan. Hydrol. Process. 2018, 32, 1235-1253. [CrossRef]

32. Mcarthur, J.M.; Sikdar, P.K.; Leng, M.J.; Ghosal, U.; Sen, I. Groundwater Quality beneath an Asian Megacity on a Delta: Kolkata's (Calcutta's) Disappearing Arsenic and Present Manganese. Environ. Sci. Technol. 2018, 52, 5161-5172. [CrossRef] [PubMed]

33. Gillispie, E.; Polizzotto, M.; Jones, M. Investigating the role of sediment manganese as a potential predictor for future arsenic contamination of groundwater. In Abstracts of Papers of the American Chemical Society; American Chemical Society: Washington, DC, USA, 2017.

34. Scott, M.J.; Morgan, J.J. Reactions at oxide surfaces. 1. Oxidation of As(III) by synthetic Birnessite. Environ. Sci. Technol. 1995, 29, 1898-1905. [CrossRef] [PubMed]

35. Nesbitt, H.W.; Canning, G.W.; Bancroft, G.M. XPS study of reductive dissolution of $7 \AA$ A-birnessite by $\mathrm{H}_{3} \mathrm{AsO}_{3}$, with constraints on reaction mechanism. Geochim. Cosmochim. Acta 1998, 62, 2097-2110. [CrossRef]

36. Tournassat, C.; Charlet, L.; Bosbach, D.; Manceau, A. Arsenic(III) Oxidation by Birnessite and Precipitation of Manganese(II) Arsenate. Environ. Sci. Technol. 2002, 36, 493-500. [CrossRef] [PubMed]

37. Lafferty, B.J.; Ginder-Vogel, M.; Sparks, D.L. Arsenite oxidation by a poorly crystalline manganese-oxide 1. Stirred-flow experiments. Environ. Sci. Technol. 2010, 44, 8460-8466. [CrossRef] [PubMed]

38. Oscarson, D.W.; Huang, P.M.; Liaw, W.K.; Hammer, U.T. Kinetics of oxidation of arsenite by various manganese dioxides. Soil Sci. Soc. Am. J. 1983, 47, 644-648. [CrossRef]

39. Tebo, B.M.; Bargar, J.R.; Clement, B.G.; Dick, G.J.; Murray, K.J.; Parker, D.; Verity, R.; Webb, S.M. Biogenic Manganese Oxides: Properties and Mechanisms of Formation. Annu. Rev. Earth Planet. Sci. 2004, 32, 287-328. [CrossRef]

40. Duckworth, O.W.; Rivera, N.A.; Gardner, T.G.; Andrews, M.Y.; Santelli, C.M.; Polizzotto, M.L. Morphology, structure, and metal binding mechanisms of biogenic manganese oxides in a superfund site treatment system. Environ. Sci. Process. Impacts 2017, 19, 50-58. [CrossRef] [PubMed]

41. Ilton, E.S.; Post, J.E.; Heaney, P.J.; Ling, F.T.; Kerisit, S.N. XPS determination of Mn oxidation states in Mn (hydr)oxides. Appl. Surf. Sci. 2016, 366, 475-485. [CrossRef]

42. Hem, J.D. Rates of manganese oxidation in aqueous systems. Geochim. Cosmochim. Acta 1981, 45, 1369-1374. [CrossRef]

43. Villalobos, M.; Toner, B.; Bargar, J.; Sposito, G. Characterization of the manganese oxide produced by Pseudomonas putida strain MnB1. Geochim. Cosmochim. Acta 2003, 67, 2649-2662. [CrossRef]

44. Webb, S.M.; Dick, G.J.; Bargar, J.R.; Tebo, B.M. Evidence for the presence of Mn(III) intermediates in the bacterial oxidation of Mn(II). Proc. Natl. Acad. Sci. USA 2005, 102, 5558-5563. [CrossRef] [PubMed]

45. Droz, B.; Dumas, N.; Duckworth, O.W.; Peña, J. A comparison of the sorption reactivity of bacteriogenic and mycogenic Mn oxide nanoparticles. Environ. Sci. Technol. 2015, 49, 4200-4208. [CrossRef] [PubMed] 
46. Santelli, C.M.; Webb, S.M.; Dohnalkova, A.C.; Hansel, C.M. Diversity of Mn oxides produced by Mn(II)-oxidizing fungi. Geochim. Cosmochim. Acta 2011, 75, 2762-2776. [CrossRef]

47. Zhu, M. Structure and Reactivity Study of Biotic and Abiotic Poorly Crystalline Manganese Oxides. Ph.D. Thesis, University of Delaware, Newark, DE, USA, 2010.

48. Zhu, M.; Paul, K.W.; Kubicki, J.D.; Sparks, D.L. Quantum chemical study of arsenic(III, V) adsorption on Mn-oxides: Implications for arsenic(III) oxidation. Environ. Sci. Technol. 2009, 43, 6655-6661. [CrossRef] [PubMed]

49. Feng, X.; Zu, Y.; Tan, W.; Liu, F. Arsenite oxidation by three types of manganese oxides. J. Environ. Sci. 2006, 18, 292-298.

50. Fischel, M.H.; Fischel, J.S.; Lafferty, B.J.; Sparks, D.L. The influence of environmental conditions on kinetics of arsenite oxidation by manganese-oxides. Geochem. Trans. 2015, 16, 15. [CrossRef] [PubMed]

51. Marafatto, F.F.; Lanson, B.; Peña, J. Crystal growth and aggregation in suspensions of $\delta-\mathrm{MnO}_{2}$ nanoparticles: Implications for surface reactivity. Environ. Sci. Nano 2018, 5, 497-508. [CrossRef]

52. Feng, X.; Tan, W.; Liu, F.; Ruan, H.D.; Jizheng, H. Oxidation of As(III) by several manganese oxide minerals in absence and presence of goethite. Acta Geol. Sin. 2006, 80, 249-256.

53. Wang, Y.; Benkaddour, S.; Marafatto, F.F.; Peña, J. Diffusion- and pH-Dependent Reactivity of Layer-Type $\mathrm{MnO}_{2}$ : Reactions at Particle Edges versus Vacancy Sites. Environ. Sci. Technol. 2018, 52, 3476-3485. [CrossRef] [PubMed]

54. Wang, Y.; Feng, X.; Villalobos, M.; Tan, W.; Liu, F. Sorption behavior of heavy metals on birnessite: Relationship with its Mn average oxidation state and implications for types of sorption sites. Chem. Geol. 2012, 292-293, 25-34. [CrossRef]

55. Villalobos, M.; Escobar-Quiroz, I.N.; Salazar-Camacho, C. The influence of particle size and structure on the sorption and oxidation behavior of birnessite: I. Adsorption of As(V) and oxidation of As(III). Geochim. Cosmochim. Acta 2014, 125, 564-581. [CrossRef]

56. Lafferty, B.J.; Ginder-vogel, M.; Zhu, M.; Livi, K.J.T.; Sparks, D.L. Arsenite oxidation by a poorly crystalline manganese-oxide. 2. Results from X-ray absorption spectroscopy and X-ray diffraction. Environ. Sci. Technol. 2010, 44, 8467-8472. [CrossRef] [PubMed]

57. Balgooyen, S.; Alaimo, P.J.; Remucal, C.K.; Ginder-Vogel, M. Structural Transformation of $\mathrm{MnO}_{2}$ during the Oxidation of Bisphenol A. Environ. Sci. Technol. 2017, 51, 6053-6062. [CrossRef] [PubMed]

58. Feng, X.H.; Zhai, L.M.; Tan, W.F.; Liu, F.; He, J.Z. Adsorption and redox reactions of heavy metals on synthesized Mn oxide minerals. Environ. Pollut. 2007, 147, 366-373. [CrossRef] [PubMed]

59. Zhu, M.; Farrow, C.L.; Post, J.E.; Livi, K.J.T.; Billinge, S.J.L.; Ginder-Vogel, M.; Sparks, D.L. Structural study of biotic and abiotic poorly-crystalline manganese oxides using atomic pair distribution function analysis. Geochim. Cosmochim. Acta 2012, 81, 39-55. [CrossRef]

60. Murray, J.W. The interaction of metal ions at the manganese dioxide solution interface. Geochim. Cosmochim. Acta 1975, 39, 505-519. [CrossRef]

61. Händel, M.; Rennert, T.; Totsche, K.U. A simple method to synthesize birnessite at ambient pressure and temperature. Geoderma 2013, 193-194, 117-121. [CrossRef]

62. Zhu, M.; Ginder-Vogel, M.; Parikh, S.J.; Feng, X.H.; Sparks, D.L. Cation effects on the layer structure of biogenic Mn-oxides. Environ. Sci. Technol. 2010, 44, 4465-4471. [CrossRef] [PubMed]

63. Ginder-Vogel, M.; Landrot, G.; Fischel, J.S.; Sparks, D.L. Quantification of rapid environmental redox processes with quick-scanning X-ray absorption spectroscopy (Q-XAS). Proc. Natl. Acad. Sci. USA 2009, 106, 16124-16128. [CrossRef] [PubMed]

64. Han, X.; Li, Y.L.; Gu, J.D. Oxidation of $\mathrm{As}(\mathrm{III})$ by $\mathrm{MnO}_{2}$ in the absence and presence of Fe(II) under acidic conditions. Geochim. Cosmochim. Acta 2011, 75, 368-379. [CrossRef]

65. Fischel, J.S.; Fischel, M.H.; Sparks, D.L. Advances in understanding reactivity of manganese oxides with arsenic and chromium in environmental systems. In Advances in the Environmental Biogeochemistry of Manganese Oxides; American Chemical Society: Washington, DC, USA, 2015; Volume 1197, pp. 1-27. [CrossRef]

66. Jones, L.C.; Lafferty, B.J.; Sparks, D.L. Additive and competitive effects of bacteria and Mn oxides on arsenite oxidation kinetics. Environ. Sci. Technol. 2012, 46, 6548-6555. [CrossRef] [PubMed]

67. Power, L.E.; Arai, Y.; Sparks, D.L. Zinc adsorption effects on arsenite oxidation kinetics at the birnessite-water interface. Environ. Sci. Technol. 2005, 39, 181-187. [CrossRef] [PubMed] 
68. Katsoyiannis, I.A.; Zouboulis, A.I.; Jekel, M. Kinetics of Bacterial As(III) Oxidation and Subsequent As(V) Removal by Sorption onto Biogenic Manganese Oxides during Groundwater Treatment. Ind. Eng. Chem. Res. 2003, 43, 486-493. [CrossRef]

69. Tani, Y.; Miyata, N.; Ohashi, M.; Ohnuki, T.; Seyama, H.; Iwahori, K.; Soma, M. Interaction of inorganic arsenic with biogenic manganese oxide produced by a Mn-oxidizing fungus, strain KR21-2. Environ. Sci. Technol. 2004, 38, 6618-6624. [CrossRef] [PubMed]

70. Manning, B.; Fendorf, S.E.; Bostick, B.; Suarez, D.L. Arsenic(III) Oxidation and Arsenic(V) Adsorption Reactions on Synthetic Birnessite. Environ. Sci. Technol. 2002, 36, 976-981. [CrossRef] [PubMed]

71. Moore, J.N.; Walker, J.R.; Hayes, T.H. Reaction scheme for the oxidation of As(III) to As(V) by birnessite. Clays Clay Miner. 1990, 38, 549-555. [CrossRef]

72. Hou, J.; Xiang, Y.; Zheng, D.; Li, Y.; Xue, S.; Wu, C.; Hartley, W.; Tan, W. Morphology-dependent enhancement of arsenite oxidation to arsenate on birnessite-type manganese oxide. Chem. Eng. J. 2017, 327, 235-243. [CrossRef]

73. Thanabalasingam, P.; Pickering, W.F. Effect of $\mathrm{pH}$ on interaction between $\mathrm{As}(\mathrm{III})$ or $\mathrm{As}(\mathrm{V})$ and manganese(IV) oxide. Water Air Soil Pollut. 1986, 29, 205-216. [CrossRef]

74. Parikh, S.J.; Lafferty, B.J.; Meade, T.G.; Sparks, D.L. Evaluating environmental influences on As(III) oxidation kinetics by a poorly crystalline Mn-oxide. Environ. Sci. Technol. 2010, 44, 3772-3778. [CrossRef] [PubMed]

75. Corbett, J.F. Pseudo first-order kinetics. J. Chem. Educ. 1972, 49, 663. [CrossRef]

76. Cern, M. Krautite, Mn (HTOXAsOTOH): Crystal structure, hydrogen bonding and relations with haidingerite and pharmacolite. Am. Mineral. 1979, 64, 1248-1254.

77. Driehaus, W.; Seith, R.; Jekel, M. Oxidation of arsenate(III) with manganese oxides in water treatment. Water Res. 1995, 29, 297-305. [CrossRef]

78. Mitsunobu, S.; Takahashi, Y.; Uruga, T. Observation of chemical reactions at the solid-water interface by quick XAFS combined with a column reactor. Anal. Chem. 2006, 78, 7040-7043. [CrossRef] [PubMed]

79. Kumar, K.V.; Porkodi, K.; Rocha, F. Langmuir-Hinshelwood kinetics-A theoretical study. Catal. Commun. 2008, 9, 82-84. [CrossRef]

80. Silvester, E.; Manceau, A.; Drits, V.A. Structure of synthetic monoclinic Na-rich birnessite and hexagonal birnessite: II. Results from chemical studies and EXAFS spectroscopy. Am. Mineral. 1997, 82, 962-978. [CrossRef]

81. Birkner, N.; Navrotsky, A. Thermodynamics of manganese oxides: Sodium, potassium, and calcium birnessite and cryptomelane. Proc. Natl. Acad. Sci. USA 2017, 114, E1046-E1053. [CrossRef] [PubMed]

82. Zhao, W.; Feng, X.; Tan, W.; Liu, F.; Ding, S. Relation of lead adsorption on birnessites with different average oxidation states of manganese and release of $\mathrm{Mn}^{2+} / \mathrm{H}^{+} / \mathrm{K}^{+}$. J. Environ. Sci. 2009, 21, 520-526. [CrossRef]

83. Institut International du Manganèse (IMnI). Manganese in Groundwater: Research and Potential Risks; Institut International du Manganèse: Paris, France, 2013; pp. 2-3.

84. Perez-Benito, J.F. Reduction of colloidal manganese dioxide by manganese(II). J. Colloid Interface Sci. 2002, 248, 130-135. [CrossRef] [PubMed]

85. Morgan, J.J. Manganese in natural waters and Earth's crust: Its availability to organisms. In Metal Ions in Biological Systems, Manganese and Its Role in Biological Processes; Sigel, A., Sigel, H., Eds.; Metal Ions in Biological Systems; Marcel Dekker: New York, NY, USA, 2000; pp. 1-33. ISBN 0824702883.

86. Elzinga, E.J.; Kustka, A.B. A Mn-54 radiotracer study of Mn isotope solid-liquid exchange during reductive transformation of vernadite $\left(\delta-\mathrm{MnO}_{2}\right)$ by aqueous $\mathrm{Mn}(\mathrm{II})$. Environ. Sci. Technol. 2015, 49, 4310-4316. [CrossRef] [PubMed]

87. Scott, M.J. Kinetics of Adsorption and Redox Processes on Iron and Manganese Oxides: Reactions of As(III) and Se(IV) at Goethite and Birnessite Surfaces. Ph.D. Thesis, California Institute of Technology, Pasadena, CA, USA, 1991.

88. Churchman, G.J.; Lowe, D.J. Handbook of Soil Sciences: Properties and Processes; Huang, P.M., Li, Y., Sumner, M.E., Eds.; CRC Press: Boca Raton, FL, USA, 2012; ISBN 978-1-4398-0305-9.

89. Villalobos, M. The Role of Surface Edge Sites in Metal(loid) Sorption to Poorly-Crystalline Birnessites. In Advances in the Environmental Biogeochemistry of Manganese Oxides; American Chemical Society: Washington, DC, USA, 2015; pp. 65-87.

90. Fendorf, S.; Nico, P.S.; Kocar, B.D.; Masue, Y.; Tufano, K.J. Arsenic Chemistry in Soils and Sediments. In Developments in Soil Science; Elsevier: New York, NY, USA, 2010; Volume 34, pp. 357-378. ISBN 0166-2481. 
91. Machesky, M.L. Influence of temperature on ion adsorption by hydrous metal oxides. In Chemical Modeling of Aqueous Systems II; ACS: Washington, DC, USA, 1990; Volume 416, pp. 282-292. [CrossRef]

92. Kosmulski, M. Isoelectric points and points of zero charge of metal (hydr)oxides: 50 years after Parks' review. Adv. Colloid Interface Sci. 2016, 238, 1-61. [CrossRef] [PubMed]

93. Kosmulski, M. Surface Charging and Points of Zero Charge; Surfactant Science; CRC Press: Boca Raton, FL, USA, 2009; Volume 145, ISBN 9786612111105.

94. Xu, H.; Allard, B.; Grimvall, A. Influence of $\mathrm{pH}$ and organic substance on the adsorption of As(V) on geologic materials. Water Air Soil Pollut. 1988, 40, 293-305. [CrossRef]

95. Bowell, R.J. Sorption of arsenic by iron oxides and oxyhydroxides in soils. Appl. Geochem. 1994, 9, $279-286$. [CrossRef]

96. Welch, A.H.; Stollenwerk, K.G. (Eds.) Arsenic in Ground Water: Geochemistry and Occurance; Springer Science \& Business Media: Berlin, Germany, 2003.

97. Liu, H.; Chen, T.; Frost, R.L. An overview of the role of goethite surfaces in the environment. Chemosphere 2014, 103, 1-11. [CrossRef] [PubMed]

98. Kosmulski, M.; Maczka, E.; Jartych, E.; Rosenholm, J.B. Synthesis and characterization of goethite and goethite-hematite composite: Experimental study and literature survey. Adv. Colloid Interface Sci. 2003, 103, 57-76. [CrossRef]

99. Gupta, S.K.; Chen, K.Y. Arsenic Removal by Adsorption. J. Water Pollut. Control Feder. 1978, 50, 493-506.

100. Masue, Y.; Loeppert, R.H.; Kramer, T.A. Arsenate and arsenite adsorption and desorption behavior on coprecipitated aluminum: Iron hydroxides. Environ. Sci. Technol. 2007, 41, 837-842. [CrossRef] [PubMed]

101. Waychunas, G.A.; Rea, B.A.; Fuller, C.C.; Davis, J.A. Surface chemistry of ferrihydrite: Part 1. EXAFS studies ongeometrie of coprecipitated and adsorbed arsenate. Geochim. Cosmochim. Acta 1993, 57, 2251-2269. [CrossRef]

102. Sun, X.; Doner, H.E. An investigation of arsenate and arsenite bonding structures on goethite by FTIR. Soil Sci. 1996, 161, 865-872. [CrossRef]

103. Sun, X.; Doner, H.E. Adsorption and oxidation of arsenite on goethite. Soil Sci. 1998, 163, 278-287. [CrossRef]

104. Goldberg, S.; Johnston, C.T. Mechanisms of Arsenic Adsorption on Amorphous Oxides Evaluated Using Macroscopic Measurements, Vibrational Spectroscopy, and Surface Complexation Modeling. J. Colloid Interface Sci. 2001, 234, 204-216. [CrossRef] [PubMed]

105. Ona-Nguema, G.; Morin, G.; Juillot, F.; Calas, G.; Brown, G.E. EXAFS analysis of arsenite adsorption onto two-line ferrihydrite, hematite, goethite, and lepidocrocite. Environ. Sci. Technol. 2005, 39, 9147-9155. [CrossRef] [PubMed]

106. Catalano, J.G.; Zhang, Z.; Park, C.; Fenter, P.; Bedzyk, M.J. Bridging arsenate surface complexes on the hematite (0 12 ) surface. Geochim. Cosmochim. Acta 2007, 71, 1883-1897. [CrossRef]

107. Manning, B.A.; Fendorf, S.E.; Goldberg, S. Surface structures and stability of arsenic(III) on goethite: Spectroscopic evidence for inner-sphere complexes. Environ. Sci. Technol. 1998, 32, 2383-2388. [CrossRef]

108. Kocar, B.D.; Herbel, M.J.; Tufano, K.J.; Fendorf, S. Contrasting effects of dissimilatory iron(III) and arsenic(V) reduction on arsenic retention and transport. Environ. Sci. Technol. 2006, 40, 6715-6721. [CrossRef] [PubMed]

109. Catalano, J.G.; Park, C.; Fenter, P.; Zhang, Z. Simultaneous inner- and outer-sphere arsenate adsorption on corundum and hematite. Geochim. Cosmochim. Acta 2008, 72, 1986-2004. [CrossRef]

110. Wang, Y.; Morin, G.; Ona-Nguema, G.; Menguy, N.; Juillot, F.; Aubry, E.; Guyot, F.; Calas, G.; Brown, G.E. Arsenite sorption at the magnetite-water interface during aqueous precipitation of magnetite: EXAFS evidence for a new arsenite surface complex. Geochim. Cosmochim. Acta 2008, 72, 2573-2586. [CrossRef]

111. Raven, K.P.; Jain, A.; Loeppert, R.H. Arsenite and arsenate adsorption on ferrihydrite: Kinetics, equilibrium, and adsorption envelopes. Environ. Sci. Technol. 1998, 32, 344-349. [CrossRef]

112. Dixit, S.; Hering, J.G. Comparison of arsenic(V) and arsenic(III) sorption onto iron oxide minerals: Implications for arsenic mobility. Environ. Sci. Technol. 2003, 37, 4182-4189. [CrossRef] [PubMed]

113. Herbel, M.; Fendorf, S. Biogeochemical processes controlling the speciation and transport of arsenic within iron coated sands. Chem. Geol. 2006, 228, 16-32. [CrossRef]

114. Ying, S.C.; Kocar, B.D.; Fendorf, S.E. Oxidation and competitive retention of arsenic between iron- and manganese oxides. Geochim. Cosmochim. Acta 2012, 96, 294-303. [CrossRef] 
115. Zhang, G.; Liu, H.; Qu, J.; Jefferson, W. Arsenate uptake and arsenite simultaneous sorption and oxidation by Fe-Mn binary oxides: Influence of $\mathrm{Mn} / \mathrm{Fe}$ ratio, $\mathrm{pH}, \mathrm{Ca}^{2+}$, and humic acid. J. Colloid Interface Sci. 2012, 366, 141-146. [CrossRef] [PubMed]

116. He, Y.T.; Hering, J.G. Enhancement of Arsenic(III) Sequestration by Manganese Oxides in the Presence of Iron(II). Water Air Soil Pollut. 2009, 203, 359-368. [CrossRef]

117. Tufano, K.J.; Fendorf, S. Confounding impacts of iron reduction on arsenic retention. Environ. Sci. Technol. 2008, 42, 4777-4783. [CrossRef] [PubMed]

118. Ehlert, K.; Mikutta, C.; Kretzschmar, R. Effects of manganese oxide on arsenic reduction and leaching from contaminated floodplain soil. Environ. Sci. Technol. 2016, 50, 9251-9261. [CrossRef] [PubMed]

119. Oscarson, D.W.; Huang, P.M.; Hammer, U.T.; Liaw, W.K. Oxidation and Sorption of Arsenite by Manganese-Dioxide As Influenced By Surface-Coatings of Iron and Aluminum-Oxides and Calcium-Carbonate. Water Air Soil Pollut. 1983, 20, 233-244. [CrossRef]

120. Deschamps, E.; Ciminelli, V.S.T.; Weidler, P.G.; Ramos, A.Y. Arsenic sorption onto soils enriched in Mn and Fe minerals. Clays Clay Miner. 2003, 51, 197-204. [CrossRef]

121. Deschamps, E.; Ciminelli, V.S.T.; Höll, W.H. Removal of As(III) and As(V) from water using a natural Fe and Mn enriched sample. Water Res. 2005, 39, 5212-5220. [CrossRef] [PubMed]

122. Ouvrard, S.; de Donato, P.; Simonnot, M.O.; Begin, S.; Ghanbaja, J.; Alnot, M.; Duval, Y.B.; Lhote, F.; Barres, O.; Sardin, M. Natural manganese oxide: Combined analytical approach for solid characterization and arsenic retention. Geochim. Cosmochim. Acta 2005, 69, 2715-2724. [CrossRef]

123. Zhang, G.S.; Qu, J.H.; Liu, H.J.; Liu, R.P.; Li, G.T. Removal mechanism of As(III) by a novel Fe-Mn binary oxide adsorbent: Oxidation and sorption. Environ. Sci. Technol. 2007, 41, 4613-4619. [CrossRef] [PubMed]

124. Shan, C.; Tong, M. Efficient removal of trace arsenite through oxidation and adsorption by magnetic nanoparticles modified with Fe-Mn binary oxide. Water Res. 2013, 47, 3411-3421. [CrossRef] [PubMed]

125. Qi, J.; Zhang, G.; Li, H. Efficient removal of arsenic from water using a granular adsorbent: Fe-Mn binary oxide impregnated chitosan bead. Bioresour. Technol. 2015, 193, 243-249. [CrossRef] [PubMed]

126. Joshi, T.P.; Zhang, G.; Jefferson, W.A.; Perfilev, A.V.; Liu, R.; Liu, H.; Qu, J. Adsorption of aromatic organoarsenic compounds by ferric and manganese binary oxide and description of the associated mechanism. Chem. Eng. J. 2017, 309, 577-587. [CrossRef]

127. Behrendt, H.; Boekhold, A. Phosphorus saturation in soils and groundwaters. Land Degrad. Dev. 1993, 4, 233-243. [CrossRef]

128. Masue-Slowey, Y.; Kocar, B.D.; Bea Jofré, S.A.; Mayer, K.U.; Fendorf, S. Transport implications resulting from internal redistribution of arsenic and iron within constructed soil aggregates. Environ. Sci. Technol. 2011, 45, 582-588. [CrossRef] [PubMed]

129. Persson, I. Hydrated metal ions in aqueous solution: How regular are their structures? Pure Appl. Chem. 2010, 82, 1901-1917. [CrossRef]

130. Tani, Y.; Ohashi, M.; Miyata, N.; Seyama, H.; Iwahori, K.; Soma, M. Sorption of Co.(II), Ni(II), and Zn(II) on biogenic manganese oxides produced by a Mn-oxidizing fungus, strain KR21-2. J. Environ. Sci. Health Part A 2004, 39, 2641-2660. [CrossRef]

131. Mukhopadhyay, R.; Rosen, B.P.; Phung, L.T.; Silver, S. Microbial arsenic: From geocycles to genes and enzymes. FEMS Microbiol. Rev. 2002, 26, 311-325. [CrossRef] [PubMed]

132. Oremland, R.S.; Stolz, J.F. The ecology of arsenic. Science 2003, 300, 939-944. [CrossRef] [PubMed]

133. Rhine, E.D.; Garcia-Dominguez, E.; Phelps, C.D.; Young, L.Y. Environmental microbes can speciate and cycle arsenic. Environ. Sci. Technol. 2005, 39, 9569-9573. [CrossRef] [PubMed]

134. Garcia-Dominguez, E.; Mumford, A.; Rhine, E.D.; Paschal, A.; Young, L.Y. Novel autotrophic arsenite-oxidizing bacteria isolated from soil and sediments. FEMS Microbiol. Ecol. 2008, 66, 401-410. [CrossRef] [PubMed]

135. Silver, S.; Phung, L.T. Genes and enzymes involved in bacterial oxidation and reduction of inorganic arsenic. Appl. Environ. Microbiol. 2005, 71, 599-608. [CrossRef] [PubMed]

136. Ying, S.C.; Kocar, B.D.; Griffis, S.D.; Fendorf, S. Competitive Microbially and Mn Oxide Mediated Redox Processes Controlling Arsenic Speciation and Partitioning. Environ. Sci. Technol. 2011, 45, 5572-5579. [CrossRef] [PubMed]

137. Shumlas, S.L.; Singireddy, S.; Thenuwara, A.C.; Attanayake, N.H.; Reeder, R.J.; Strongin, D.R. Oxidation of arsenite to arsenate on birnessite in the presence of light. Geochem. Trans. 2016, 17, 5. [CrossRef] [PubMed] 
138. Morgan, J.J. Kinetics of reaction between $\mathrm{O} 2$ and $\mathrm{Mn}(\mathrm{II})$ species in aqueous solutions. Geochim. Cosmochim. Acta 2005, 69, 35-48. [CrossRef]

139. Feng, X.; Wang, P.; Shi, Z.; Kwon, K.D.; Zhao, H.; Yin, H.; Lin, Z.; Zhu, M.; Liang, X.; Liu, F.; Sparks, D.L. A Quantitative Model for the Coupled Kinetics of Arsenic Adsorption/Desorption and Oxidation on Manganese Oxides. Environ. Sci. Technol. Lett. 2018, 5, 175-180. [CrossRef]

140. Sherman, D.M.; Randall, S.R. Surface complexation of arsenic(V) to iron(III) (hydr)oxides: Structural mechanism from ab initio molecular geometries and EXAFS spectroscopy. Geochim. Cosmochim. Acta 2003, 67, 4223-4230. [CrossRef]

141. Appelo, C.A.J.; Van Der Weiden, M.J.J.; Tournassat, C.; Charlet, L. Surface complexation of ferrous iron and carbonate on ferrihydrite and the mobilization of arsenic. Environ. Sci. Technol. 2002, 36, 3096-3103. [CrossRef] [PubMed]

142. Sverjensky, D.A.; Fukushi, K. A predictive model (ETLM) for As(III) adsorption and surface speciation on oxides consistent with spectroscopic data. Geochim. Cosmochim. Acta 2006, 70, 3778-3802. [CrossRef]

143. Appelo, C.A.J.; Postma, D. A consistent model for surface complexation on birnessite(- $\left.\mathrm{MnO}_{2}\right)$ and its application to a column experiment. Geochim. Cosmochim. Acta 1999, 63, 3039-3048. [CrossRef]

144. Tonkin, J.W.; Balistrieri, L.S.; Murray, J.W. Modeling sorption of divalent metal cations on hydrous manganese oxide using the diffuse double layer model. Appl. Geochem. 2004, 19, 29-53. [CrossRef]

145. Pretorius, P.J.; Linder, P.W. The adsorption characteristics of $\delta$-manganese dioxide: A collection of diffuse double layer constants for the adsorption of $\mathrm{H}^{+}, \mathrm{CU}^{2+}, \mathrm{NI}^{2+}, \mathrm{zn}^{2+}, \mathrm{CD}^{2+}$ and $\mathrm{PB}^{2+}$. Appl. Geochem. 2001, 16, 1067-1082. [CrossRef]

146. Peacock, C.L.; Sherman, D.M. Sorption of Ni by birnessite: Equilibrium controls on Ni in seawater. Chem. Geol. 2007, 238, 94-106. [CrossRef]

147. Essington, M.E.; Vergeer, K.A. Adsorption of Antimonate, Phosphate, and Sulfate by Manganese Dioxide: Competitive Effects and Surface Complexation Modeling. Soil Sci. Soc. Am. J. 2015, 79, 803-814. [CrossRef]

148. Pan, Z.; Li, W.; Fortner, J.D.; Giammar, D.E. Measurement and Surface Complexation Modeling of U(VI) Adsorption to Engineered Iron Oxide Nanoparticles. Environ. Sci. Technol. 2017, 51, 9219-9226. [CrossRef] [PubMed]

149. Hiemstra, T.; Van Riemsdijk, W.H. A Surface Structural Approach to Ion Adsorption: The Charge Distribution (CD) Model. J. Colloid Interface Sci. 1996, 179, 488-508. [CrossRef]

150. Mangold, J.E.; Park, C.M.; Liljestrand, H.M.; Katz, L.E. Surface complexation modeling of Hg(II) adsorption at the goethite/ water interface using the Charge Distribution Multi-Site Complexation (CD-MUSIC) model. J. Colloid Interface Sci. 2014, 418, 147-161. [CrossRef] [PubMed]

151. Mayer, K.U.; Frind, E.O.; Blowes, D.W. Multicomponent reactive transport modeling in variably saturated porous media using a generalized formulation for kinetically controlled reactions. Water Resour. Res. 2002, 38, 13-1-13-21. [CrossRef]

(C) 2018 by the authors. Licensee MDPI, Basel, Switzerland. This article is an open access article distributed under the terms and conditions of the Creative Commons Attribution (CC BY) license (http:/ / creativecommons.org/licenses/by/4.0/). 